Izvorni članak UDK 1 Schelling, F. W. J.

1 Heidegger, $M$.

doi: $10.21464 /$ fi40101

Primljeno 8. 10. 2019.

\title{
Damir Barbarić
}

Institut za filozofiju, Ulica grada Vukovara 54, HR-10000 Zagreb

barba@ifzg.hr

\section{Indiferencija i opuštenost}

\section{Heidegger u svjetlu Schellinga}

\begin{abstract}
Sažetak
U članku se nastoji istražiti i što preciznije odrediti višestruko složeni odnos Heideggerova mišljenja spram Schellingove filozofije. Od početne fascinacije Schellingovim središnjim spisom o slobodi, u kojem nalazi značajne analogije s vlastitim pokušajima promišljanja konačnosti slobode, a time i samog bitka, Heidegger će se u daljnjem razvijanju vlastita mišljenja od Schellinga sve više $i$ sve oštrije distancirati, prigovarajući mu da ne uspijeva prevladati metafiziku, već ostaje u njezinu vidokrugu, premda na izniman i u svakom pogle$d u$ respektabilan način. Primjerenost te prosudbe u članku se stavlja u pitanje i svestrano propituje kritičkom usporedbom i temeljitom pojmovnom analizom Schellingova shvaćanja volje, indiferencije, ljubavi i ekstaze s jedne, te Heideggerova shvaćanja zla, volje za voljom, bezdana i opuštenosti s druge strane. Pritom na vidjelo zaključno izlazi stvarna srodnost tih središnjih pojmova kasne filozofije jednog i drugog mislioca, koja je mnogo veća nego što je to Heidegger bio spreman uvidjeti i iskoristiti za krajnje svrhe vlastita mišljenja.
\end{abstract}

\section{Ključne riječi}

Friedrich Wilhelm Joseph Schelling, Martin Heidegger, sloboda, volja, indiferencija, zlo, opuštenost

Odavno je poznato kako veliko je za Heideggera bilo značenje Schellingova spisa o slobodi, i to upravo u vrijeme njegova prijelaza u navlastito kasno mišljenje. ${ }^{1}$ Uvijek iznova spominje se njegova pohvala te rasprave kao »jednog od najdubljih djela njemačke, a time i zapadnjačke filozofije «, ${ }^{2} \mathrm{kao}$ i prosudba da je Schelling »uistinu stvaralački i najdalje sežući mislilac cijeloga

1

Autorov prijevod (uz neznatne izmjene i dopune) rasprave »Indifferenz und Gelassenheit. Heidegger im Lichte Schellings«, izložene u skraćenoj verziji kao predavanje na konferenciji »Sein, Grund, Ungrund - Schellings Bedeutung für das Denken Heideggers«, održanoj 9. - 10. svibnja 2019. na Freiburg Institut for Advanced Studies Albert-Ludwigs Universität Freiburg u Freiburgu, Njemačka.

2

Martin Heidegger, Schellings Abhandlung über das Wesen der menschlichen Freiheit (1809.), Hildegard Feick (ur.), Max Niemeyer
Verlag, Tübingen 1971., str. 2 (= Martin Heidegger, Schelling: Vom Wesen der menschlichen Freiheit (1809.), Ingrid Schüßler (ur.), GA 42, Vittorio Klostermann, Frankfurt am Main 1988., str. 3). Radi lakše dostupnosti ovo djelo nadalje se navodi prema starijem i poznatijem izdanju, pri čemu je (osim u slučajevima nepodudaranja teksta) u zagradama uz oznaku GA 42 dodan broj stranice sveska objavljenog u okviru Heideggerovih Sabranih djela. 
tog razdoblja njemačke filozofije $\ll^{3}$ Karlu Jaspersu, koji ga je na Schellinga prvi upozorio, Heidegger 24. travnja 1926. piše:

»Na Schellingovoj knjižici moram Vam danas još jednom izričito zahvaliti. Schelling se filozofski upušta mnogo dalje nego Hegel, premda je pojmovno neuredniji. ${ }^{4}$

Čini se da su za tako visoku ocjenu dva razloga bila odlučujuća. Kao prvo, Heidegger u Schellinga nalazi onu egzistencijalnu izvornost, koju sam strastveno traži od vremena svojih prvih pokušaja hermeneutičkog izlaganja faktičnosti, a koja bi trebala prethoditi svemu puko logičkom i apstraktno pojmovnom te bi tako mogla otključati i na vidjelo iznijeti čak i najdublje slojeve bitka. S očiglednim slaganjem Heidegger ustvrđuje:

»Schelling ne misli 'pojmove', on misli sile i on misli u voljnim držanjima, misli u sukobu moći koje se pojmovnim umijećem ne daju dovesti do ujednačenja. « 5

U Schellingovu djelu prepoznaje nakanu koja mu i samom lebdi pred očima, naime zasnivanje takva mišljenja »koje, umjesto da isporučuje predodžbe i pojmove, sebe iskušava i okušava kao mijenu samog odnošenja spram bitka.$^{6} \mathrm{Na}$ toj pozadini treba razumjeti i njegov izazovan i mnogima začudan nazor da je Schellingov spis o slobodi takva rasprava »koja iz temelja potresa Hegelovu 'logiku' još prije njezina pojavljivanja«.

Kao drugo, Schellingova ishodišna postavka, prema kojoj sloboda »nije tek sposobnost među drugima, već sposobnost svih sposobnosti «, ${ }^{8}$ u punom je suglasju s Heideggerovim tadašnjim shvaćanjima. Možda on upravo zato i nesvjesno naginje tomu da Schellingov pojam slobode ponekad, često upravo u bitnim aspektima, shvaća i tumači iz obzorja vlastite filozofije. Na primjer, pri objašnjenju istovjetnosti prave slobode s nužnošću, koju Schelling pokazuje na činjenici čovjekova u inteligibilnom činu izvršena određenja sama sebe, za koje mu nije potreban, pa čak ni moguć, nikakav izbor, Heidegger se neskriveno oslanja na vlastito naučavanje o odlučnosti razrađeno u Bitku i vreтепи:

»Tko tek bira i hoće birati, taj tako još zapravo ne zna što hoće; on još niti neće na izvoran način. Tko je odlučan, taj to već zna. Odluka za odlučnost i znanje sama sebe u jasnoći najvlastitije biti jedno je i isto. ${ }^{9}$

Tako protumačeno jedinstvo slobode i nužnosti Heidegger zatim dovodi u vezu s onim što je sam u svojem glavnom djelu izložio kao »trenutak«. Tamo gdje se vremenitost istinski zbiva, naime u odlučnom trenutku, u kojem bilost i budućnost zajedno udaraju u sadašnjost te čovjeka njegova vlastita prava bit poput bljeska pogađa kao upravo ta i njegova, tamo čovjek iskušava i uviđa da je uvijek već morao biti taj koji upravo jest, kao onaj koji je sebe kao tog i takvog odredio. ${ }^{10} \mathrm{Tu}$, u tom središtu izvorne vremenitosti, nužnost je sloboda, a sloboda nužnost. ${ }^{11}$ Stoga u onomu što Schelling naziva »vječnošću « treba prepoznati isto ono što je u Bitku i vremenu izloženo kao izvorna vremenitost, naime takva koja se svaki put drukčije sabire u trenutku, da bi odatle izbila i proširila se u sve tri dimenzije inače obične vremenitosti:

»[T]aj udar prave vremenitosti, taj trenutak 'je' bit vječnosti, a nije to puko stojeća sadašnjost, nunc stans. Vječnost se istinski, to znači pjesnički, može misliti samo pojmimo li je kao najizvorniju vremenitost. ${ }^{12}$

Unatoč toj jasno sagledanoj i izrijekom potvrđenoj srodnosti vlastita mišljenja sa Schellingovim, početna očaranost u Heideggera ipak ubrzo splašnjava i biva zamijenjena sve oštrijom kritikom. Istovremeno s upornim nastojanjima oko »okreta« u vlastitu mišljenju on se upadljivo odvraća od Schellinga. 
Tako će, na primjer, za njegov pojam egzistencije ustvrditi da »ostaje posve unutar zapadnjačke i ujedno novovjekovne metafizike «. ${ }^{13}$ Potvrđivanje sama sebe, koje je u Schellinga jedno od osnovnih obilježja pra-bitka određenog kao htijenje, bez krzmanja će svesti na izlaganje bitka u smislu exigentia essentiae, koje je početno razradio još Leibniz, a u obzorju kojeg biće jest samo »ukoliko sama sebe u svojoj biti dostavlja i u takvom dostavljanju sebe predočava odnosno predstavlja te, predstavljajući se, stremi samom sebi «. ${ }^{14}$ Schellingovo mišljenje sad se već, usprkos još uvijek naglašavanom priznanju, promatra sve radikalnije kritički. Gomilaju se prigovori, svaki od njih dovoljno oštar i beskompromisan. Prigovara se da Schelling zapravo misli »metafizički, onto-teologijski, premda u najvišem dovršenju «. ${ }^{15}$ Također da

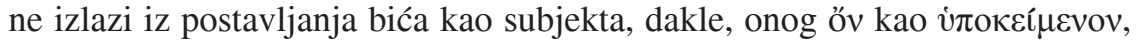
o čemu jasno svjedoči njegov kasni nauk o potencijama. ${ }^{16} \mathrm{U}$ svojem veličan-

Ibid., str. 4 (= GA 42, str. 6).

Martin Heidegger, Karl Jaspers, Briefwechsel 1920. - 1963., Walter Biemel, Hans Saner (ur.), Serie Piper, Vittorio Klostermann, München, Frankfurt am Main 1992., str. 62 I godinu i pol kasnije vrijedi ista ocjena. Usp. pismo Jaspersu od 27. rujna 1927., str. 80: »Otkad ste mi poklonili Schellingovu knjižicu rasprava o slobodi nije mi više dala mira.« 5

M. Heidegger, Schellings Abhandlung über das Wesen der menschlichen Freiheit (1809.), str. 133 (= GA 42, str. 193). Usp. str. 31 (= GA 42, str. 44): »Bitne riječi su djelovanja koja se zbivaju u onim trenucima u kojima kroz cjelinu svijeta ide munja velikog prosvjetljenja.«

Martin Heidegger, »Vom Wesen der Wahrheit«, u: Wegmarken, Friedrich-Wilhelm von Herrmann (ur.), GA 9, Vittorio Klostermann, Frankfurt am Main 1976., str. 202.

M. Heidegger, Schellings Abhandlung über das Wesen der menschlichen Freiheit (1809.), str. 117 (= GA 42, str. 168 i d.). Čini se da je Heideggerovo davanje prednosti Schellingu u odnosu spram Hegela ostalo konstantom, unatoč njegovu kasnijem odvraćanju od Schellinga. Usp. njegov načelni stav o tom pitanju u pismu Hanni Arendt 15. siječnja 1972. (Hannah Arendt, Martin Heidegger, Briefe 1925 bis 1975. und andere Zeugnisse, Ursula Ludz (ur.), Vittorio Klostermann, Frankfurt am Main 1998., str. 226): »Schelling je mnogo teži nego Hegel, on se odvažuje dalje i povremeno napušta svaku osiguravajuću obalu. Hegelu se na tračnicama dijalektike ne može ništa dogoditi.«

M. Heidegger, Schellings Abhandlung über das Wesen der menschlichen Freiheit (1809.), str. 186 (= GA 42, str. 267).
Ibid. Usp. str. 193 (= GA 42, str. 277), gdje je odlučnost označena kao »najunutarnjija jezgra apsolutne slobode $\ll$.

10

Usp. ibid., str. 186 i d. (= GA 42, str. 268).

11

Ibid., str. 187 (= GA 42, str. 268).

12

Ibid., str. 136. Claus-Artur Scheier, »Die Zeit der Seynsfuge. Zu Heideggers Interesse an Schellings Freiheitsschrift«, u: Hans Michael Baumgartner, Wilhelm G. Jacobs (ur.), Schellings Weg zur Freiheitsschrift. Legende und Wirklichkeit (Schellingiana 5), frommannholzboog, Stuttgart-Bad Cannstatt 1996., str. 28-39, uvjerljivo je pokazao da je temelj bitne srodnosti Heideggera i Schellinga u zajedničkom temeljnom iskustvu izvorne vremenitosti, kao i u s tim povezanim naučavanjima koja se najvećim dijelom podudaraju. 13

Martin Heidegger, Die Metaphysik des deutschen Idealismus. Zur erneuten Auslegung von Schelling: Philosophische Untersuchungen über das Wesen der menschlichen Freiheit und die damit zusammenhängenden Gegenstände (1809.), GA 49, Günter Seubold (ur.), Vittorio Klostermann, Frankfurt am Main 1991., str. 75.

14

Ibid., str. 86 .

15

M. Heidegger, Schellings Abhandlung über das Wesen der menschlichen Freiheit (1809.), str. 212.

16

Ibid. 
stvenom pokušaju on je u tolikoj mjeri posustao da u svojoj kasnoj filozofiji "pada natrag u ukočenu predaju, a da je nije stvaralački preinačio «. ${ }^{17}$ Prodori sadržani u njegovu spisu o slobodi, »kako to pokazuje prijelaz u 'pozitivnu filozofiju', nisu uspjeli dovesti do odluke «. ${ }^{18}$

Odakle ta iznenađujuća promjena stava i držanja? Prema svemu sudeći, uslijedila je iz Heideggerovih tadašnjih napora za prevladavanjem i napuštanjem vlastita filozofskog ishodišta, koje je od samog početka bilo snažno oslonjeno na Husserlov nauk o intencionalnosti te utoliko bitno određeno metafizičkim pojmom volje. Da bi se glavni smjer tog Heideggerova nastojanja oko »okreta « kao radikalne promjene vlastita ishodišta prikazao barem u posve sažetom orisu, potrebno se do neke mjere upustiti u sadržaj njegova članka $O$ biti temelja te njemu vremenski i sadržajno odgovarajućeg predavanja Metafizička počela logike u ishodištu od Leibniza. ${ }^{19}$ Tamo se sebe-nabacivanje tubitka na svoje mogućnosti svodi na temeljno zbivanje koje mu je u osnovi, ono naime u kojem tubitak pred sebe tek baca nešto takvo kao »ono radi čega uopće«. Taj izvorni nabačaj, kao prekoračenje svakog postojećeg bića, biva izveden voljom, ali takvom koja je i sama jednako izvorna, koja je - za razliku od bilo kojeg posebnog predočavanja, prosuđivanja ili radovanja, ali i od bilo koje određene volje - temeljno zbivanje transcendiranja, iz kojeg tek izviru svi to posebni načini odnošenja tubitka. Traga li se pak za unutarnjom mogućnošću takve izvorno shvaćene volje, naći će je se u slobodi. ${ }^{20}$ Bit tubitka svodi se dakle na slobodu. Kao izvor njegove biti, sloboda nije tek svojstvo čovjeka shvaćenog kao tubitak, nije nešto što bi on posjedovao. Uistinu je posve obrnuto, naime »sloboda, ek-sistentni, razotkrivajući tubitak posjeduje čovjeka ${ }^{21}{ }^{21}$ Heideggeru će se zato sloboda pokazati kao ono naprosto prvo i najviše, kao »ono što leži još prije bitka $i$ vremena ${ }^{22}$

Zato se »okret« - koji se uvjetno i pojednostavljeno može označiti kao premještanje filozofijskog težišta s tubitka na sam bitak - zbiva poglavito kao korjenita mijena u iskustvu i shvaćanju slobode, pri čemu se ona više ne shvaća kao apsolutna i beskonačna, već kao bitno konačna. Heideggerov »okret« je, kao odvraćanje od transcendencije, u prvom redu odvraćanje od apsolutne slobode i s njom najtješnje povezane apsolutne volje. Heidegger je postajao sve svjesniji toga da slobodu treba shvatiti u njezinoj konačnosti, a to znači bitnoj »slučajnosti

»Ali ako trebamo tražiti slobodu kao temelj mogućnosti tubitka, onda je ona sama u svojoj biti izvornija od čovjeka. Čovjek je samo namjesnik slobode, samo onaj tko slobodu onog slobodnog može na način koji ga je zapao pustiti da bude slobodom, tako da kroz čovjeka postaje vidljivom sva slučajnost slobode. $\ll^{23}$

U bitnoj činjenici da slobodni, svagda nadilazeći nabačaj svijeta tubitku »postaje moćnim i njegovim posjedom samo u uskrati« Heidegger nalazi »transcendentalni dokument konačnosti slobode tubitka«, u kojem se čak očituje i konačna bit slobode uopće «. ${ }^{24}$ Tom se spoznajom shvaćanje slobode kao »slobodno lebdeće apsolutne proizvoljnosti « razotkriva kao sasvim pogrešno i promašeno. Naprotiv, slobodu treba »pojmiti u njezinoj konačnosti te vidjeti da ona pokazivanjem njezine vezanosti nije narušena i da njezina bit time nije obrezana . $^{25}$

Kao najava Heideggerove vodeće misli o konačnom bitku kao bezdanu - koja je ovdje načinom ne samo izricanja nego i samog mišljenja još uvijek djelomice ovisna o ishodištu u transcendenciji tubitka, da bi tek kasnije bila mišljena i razvijena u cijelom svojem domašaju - sloboda će na završetku članka $O$ biti temelja biti određena kao »bez-dan odnosno bez-temelj tubitka«: 
»Ne kao da je pojedinačno slobodno odnošenje bez temelja, nego sloboda u svojoj biti kao transcendencija stavlja tubitak, kao ono što može biti, u mogućnosti koje se rastvaraju pred njegovim konačnim izborom, to znači u njegovu usudu. $\ll^{26}$

Iz svega toga proizlazi iznenađujući uvid da je bit konačne slobode u nužnosti. Taj na prvi pogled paradoksalan stav, izražen riječima da je »čista nužnost (...) ujedno oslobođenje u slobodu «, ${ }^{27}$ Heidegger je našao iskazan i temeljito obrazložen već u Schellinga. S neskrivenim odobravanjem on stoga navodi Schellingovu tvrdnju da je »prava sloboda, u smislu određenja sama sebe, samo tamo gdje izbor više nije moguć, ali nije ni potreban «. ${ }^{28}$ Jedino što mu $\mathrm{u}$ tom sklopu u Schellinga nedostaje jest uvid »da je bitak sam u biti konačan «, ${ }^{29}$ za koji smatra da bi trebao nužno proizaći iz daljeg prosljeđivanja time zacrtana misaonog pravca.

17

Ibid., str. 194 (= GA 42, str. 279).

18

Martin Heidegger, Beiträge zur Philosophie (Vom Ereignis), Friedrich-Wilhelm von Herrmann (ur.), GA 65, Vittorio Klostermann, Frankfurt am Main 1989., str. 204. Usp. M. Heidegger, Schellings Abhandlung über das Wesen der menschlichen Freiheit (1809.), str. 194 (= GA 42, str. 279). Heideggerova duboka skepsa u pogledu Schellingove pozitivne filozofije osobito jasno je do izraza došla u jednoj seminarskoj vježbi iz 1937./38. (Martin Heidegger, Seminare (Übungen) 1937./38. und 1941./42.: 1. Die metaphysischen Grundstellungen des abendländischen Denkens, 2. Einübung in das philosophische Denken, Alfred Denker (ur.), GA 88, Vittorio Klostermann, Frankfurt am Main 2008.), gdje se, među ostalim, doduše, dosta ovlašno i pojednostavljeno, osvrće na Schellingovo razlikovanje negativne i pozitivne filozofije te dolazi do sljedećeg zaključka, koji bi trebao općenito okarakterizirati kasnog Schellinga (str. 141): »Rastuća suprotstavljenost Hegelu čini ga sve ovisnijim od njega, a ono pozitivno postaje sve grublje i sve više okrenuto unatrag. Zato u kasnoj filozofiji ne leži ono doista uzbudljivo i poticajno Schellingova mišljenja, ona je u području na koje se odnosi (kršćansko-aristotelovsko-platonski svijet) samo luka spasa za brod na olujnom putu rasprave o slobodi.«

19

Usp. Damir Barbarić, Zum anderen Anfang. Studien zum Spätdenken Heideggers, Verlag Karl Alber, Freiburg, München 2016., str. 51 i d.

20

Martin Heidegger, »Vom Wesen des Grundes«, u: Wegmarken, GA 9, str. 163. Usp. Martin Heidegger, Metaphysische Anfangsgründe der Logik im Ausgang von Leibniz, Klaus Held (ur.), GA 26, Vittorio Klostermann, Frankfurt am Main 1978., str. 247: »Sloboda daje sebe razumjeti, ona je pra-razumijevanje, to znači pra-nabačaj onoga što sama omogućuje. U nabačaju onog radi čega kao takvog tubitak sebi daje izvorno vezivanje. Sloboda čini tubitak u temelju njegove biti njemu samom obveznim, točnije daje mu samu mogućnost vezivanja. Cjelina vezivanja koje leži u onom radi čega jest svijet.«

21

M. Heidegger, »Vom Wesen der Wahrheit«, str. 190.

\section{2}

Martin Heidegger, Vom Wesen der menschlichen Freiheit, Hartmut Tietjen (ur.), GA 31, Vittorio Klostermann, Frankfurt am Main 1982., str. 134

23

Ibid., str. 134.

24

M. Heidegger, »Vom Wesen des Grundes«, str. 167.

25

M. Heidegger, Metaphysische Anfangsgründe der Logik im Ausgang von Leibniz, str. 253.

26

M. Heidegger, »Vom Wesen des Grundes«, str. 174. Prema Heideggerovoj kasnijoj bilješci (isto, bilj. a) nedostatnost je te formulacije da je ona »još uvijek uzaludni pokušaj misliti tubitak uz prekrivanje istine bitka u njezinu okretu $\ll$.

27

Martin Heidegger, Grundbegriffe, Petra Jaeger (ur.), GA 51, Vittorio Klostermann, Frankfurt am Main 1981., str. 102

28

M. Heidegger, Schellings Abhandlung über das Wesen der menschlichen Freiheit (1809.), str. 186 (= GA 42, str. 268)

29

Martin Heidegger, »Was ist Metaphysik?«, u: M. Heidegger, Wegmarken, str. 120 
Ovi tek ovlašno ocrtani koraci mišljenja trebali su posvjedočiti snažnu privlačnost koju je Schellingov spis o slobodi u Heideggera početno pobudio, ali i naznačiti razloge udaljavanja i odvraćanja od njega, koje je ubrzo nastupilo. Heidegger je očito Schellinga u početku prepoznao kao filozofijskog istomišljenika i mogućeg saveznika u svojem filozofskom obračunu s Hegelom, štoviše s cijelom poviješću metafizike. Prvi glavni razlog toga bilo je, kako je rečeno, obojici zajedničko uvjerenje u istovjetnost istinske slobode s nužnošću. Drugi, općenitiji razlog ležao je u Schellingovu emfatičkom uzdizanju života i volje, te na toj osnovi snažno inzistiranje na bitnoj ulozi čovjeka u cjelini bića i na bez-temeljnom, nikakvim razlogom objašnjivom praiskonskom činu njegove vječne odnosno pred-vremene odluke.

Čini se da je Heideggerovo razmjerno naglo i iznenađujuće odvraćanje od Schellinga bilo uzrokovano uvjerenjem da se Schelling ipak nije uspio probiti do odlučujuće misli konačnosti bitka, što je za Heideggera u sklopu njegovih nastojanja oko »okreta « moralo biti razočaravajuće. Premda je vodećom mišlju apsolutne indiferencije kao posvemašnje lišenosti predikatā dospio do na sam prag toga, Schelling ipak nije izveo zaključak koji se odatle nameće, naime taj »da je bit sveg bitka konačnost «. ${ }^{30}$ Zbog toga su već u spisu o slobodi, a osobito u kasnoj filozofiji »momenti bitkovnog sklopa, temelja i egzistencije u svojem jedinstvu ne samo sve manje povezivani nego su čak toliko odvojeni jedni od drugih « da je Schelling naposljetku »pao natrag u ukočenu predaju zapadnjačkog mišljenja, a da je nije stvaralački preinačio «. ${ }^{31}$ Odatle se za Heideggera nadaje nužnost da se u službi vlastite najviše zadaće oprosti od Schellinga, ali i od same slobode, kako je to do izraza došlo u neobično oštrom, čak nepomirljivom stavu:

»Bitkopovijesno početno - 'sloboda' je svoju ulogu izgubila - jer bitak je početniji od bićevnosti i subjektivnosti. $\ll^{32}$

$$
* * *
$$

Cijeneći nespornu relevantnost i temeljitost Heideggerove interpretacije Schellinga, njezinu održivost ipak treba uvijek iznova propitivati. Jer ne može se isključiti da je Heidegger i tu, kao na primjer u slučaju Nietzschea, da bi osigurao i osnažio vlastitu poziciju ponegdje zapao u iskušenje da Schellingove bitne misli protumači jednostrano i zato nedostatno te da njihovu udaljenost od vlastitih prikaže što većom. Nedavno je upozoreno da Heideggerov zaključak da Schellingov pojam volje u potpunosti pripada novovjekoj, štoviše ukupnoj zapadnjačkoj metafizici, koja bez iznimke počiva na subjektivnosti i

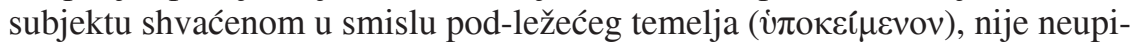
tan, osobito uzme li se u obzir središnja uloga koju u Schellinga ima opuštena, nehtijuća volja. ${ }^{33} \mathrm{U}$ tom je sklopu također napomenuto da u Schellinga i Heideggera, usprkos mnogim neporecivim razlikama, ima mnogo toga bitno zajedničkog, s posebnim naglaskom na stvarnu bliskost Schellingove »ekstaze« s Heideggerovim »okretom«, koja se svodi na obojici zajednički bitni pothvat zasnivanja jedne »teorije opuštenosti, kao nabačaja koji je suprotstavljen fiksiranosti na volju kojom je određena moderna.$^{34}$

S tim se u osnovi treba složiti. Daljnje istraživanje u tom smjeru moglo bi donijeti ne samo vrijedne uvide u granice Heideggerova tumačenja Schellinga - nesumnjivo jednog od najprodornijih i najpoticajnijih među svima dosad poduzetima - nego i najvažnije misli i stavove obojice mislilaca otvoriti za novo i dublje razumijevanje. U službi te zadaće u onomu što slijedi upustit 
ćemo se u Heideggerovu interpretaciju središnjih tema spisa o slobodi, naime volje, ljubavi i indiferencije. ${ }^{35}$

Schellingovo ishodište u volji na Heideggera je od početka ostavljalo dvoznačan, ambivalentan dojam. On se s jedne strane bez pogovora slaže da tako na najbolji način na vidjelo izlaze polarnost, napetost i prijepornost usidrene duboko u samom korijenu života i egzistencije. ${ }^{36} \mathrm{~S}$ druge strane u tomu ipak vidi opasnost da sve biće, pa čak i sam bitak, budu bez ostatka izručeni slijepom porivu za moći i neprestanoj borbi za održanje i potvrđivanje sama sebe. Jer volja, kako je on shvaća i tumači, po svojoj je najdubljoj biti poriv, nagon, požuda, čežnja:

»Pra-bitak je volja. Bitak znači volju, poriv, zato su osnovne odredbe bitka nekog bića čežnja i riječ čežnje, čežnja koja se okreće unatrag na samu sebe. « ${ }^{37}$

30

M. Heidegger, Schellings Abhandlung über das Wesen der menschlichen Freiheit (1809.), str. 195 (= GA 42, str. 280).

31

Ibid., str. 194 (= GA 42, str. 279).

32

M. Heidegger, Die Metaphysik des deutschen Idealismus, str. 231. Usp. M. Heidegger, Schellings Abhandlung über das Wesen der menschlichen Freiheit (1809.), str. 232.

33

Usp. Lore Hühn, »Heidegger - Schelling in philosophischer Zwiegespräch - Der Versuch einer Einleitung«, u: Lore Hühn, Jörg Jantzen (ur.), Heideggers Schelling Seminar (1927./28.).DieProtokollevonMartin Heideggers Seminar zu Schellings 'Freiheitsschrift' (1927./28.) und die Akten des Internationalen Schelling-Tags 2006. Lektüren F. W. J. Schellings I, Unter Mitarbeit von Philipp Schwab und Sebastian Schwenzfeuer (Schellingiana 22), frommann-holzboog, Stuttgart-Bad Cannstatt 2010., str. 3-44, osob. str. 5, 10, 21. Usp. također Sebastian Schwenzfeuer, »Natur und Sein - Affinitäten zwischen Schelling und Heidegger«, u: L. Hühn, J. Jantzen (ur.), Heideggers Schelling Seminar (1927./28.), str. 227-264, str. 246.

34

Lore Hühn, »Heidegger - Schelling in philosophischer Zwiegespräch - Der Versuch einer Einleitung «, str. 13. Usp. str. 38: »Doduše, može čuditi da Heidegger ne želi zapaziti potencijale što ih Schellingova metafizika volje ima za kritiku moderne i da mnogo toga što on mobilizira protiv Schellingove rasprave o slobodi upravo tamo dolazi do razvića, premda to ipak ne govori protiv njihova stvarnog afiniteta i unutarnje srodnosti.« Usp. daljnje izvođenje istog stava u: Lore Hühn, »Ekstase und Gelassenheit. Schelling und Heidegger im Gespräch «, JTLA. Journal of the Faculty of Letters, The University of Tokyo, Aesthetics 42-43 (2017/2018), str. 17-33. U istom smislu Günter Figal, »Schelling zwischen
Hölderlin und Nietzsche - Heidegger liest Schellings Freiheitsschrift«, u: L. Hühn, J. Jantzen (ur.), Heideggers Schelling-Seminar (1927./28.), str. 45-58, zastupa tezu da Heidegger pri svojem bitnom izjednačenju ljubavi kako je misli Schelling s moći u Nietzscheovu smislu propušta uvidjeti da »ljubav u Schellingovu smislu dolazi u blizinu onoj lebdećoj povezanosti koju Heidegger hoće dohvatiti imenom prigode« (str. 58). Jens Halfwassen pak u svojem prilogu »Freiheit als Transzendenz - Schellings Bestimmung der absoluten Freiheit in den Weltaltern und in der Philosophie der Offenbarung «, u: L. Hühn, J. Jantzen (ur.), Heideggers SchellingSeminar (1927./28.), str. 59-80, upozorava na to da apsolutna sloboda odnosno indiferencija u Schellinga - koju on, što je veoma upitno, polazeći od Plotina henologijski poistovjećuje $\mathrm{s} »$ razlike lišenim jednostavnim jedinstvom « (str. 70) - nije volja, kao što to tumači Heidegger, već naprotiv »čista ili apsolutna djelatnost, koja više nema značaj subjektivnosti« (str. 76 i d.).

35

Za početnu orijentaciju o spisu vidi zbornik: Damir Barbarić (ur.), Sloboda i zlo. Schellingov »Spis o slobodi«, Matica hrvatska, Zagreb 2017.

36

Martin Heidegger, »Schelling: Das Wesen der menschlichen Freiheit. Protokollheft aus dem WS 1927./28.«, u: Die Protokolle von Martin Heideggers Seminar zu Schellings 'Freiheitsschrift' (1927./28.) und die Akten des Internationalen Schelling-Tags 2006. Lektüren F. W. J. Schellings I, Lore Hühn, Jörg Jantzen (ur.), Unter Mitarbeit von Philipp Schwab und Sebastian Schwenzfeuer (Schellingiana 22), frommann-holzboog, Stuttgart-Bad Cannstatt 2010., str. 335 .

37

Ibid., str. 333. 
Da bi podupro to bezuvjetno poistovjećenje volje i poriva - koje nam smjesta u sjećanje priziva Schopenhauera, kojeg inače nije osobito cijenio - Heidegger se poziva na povijest metafizike, gdje je volja bila shvaćana redom

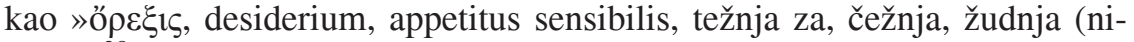
sus!) $\ll{ }^{38}$

Teško se može osporiti da je to tumačenje, kad se radi o volji temelja iz Schellingova spisa o slobodi, u osnovi ispravno. Temelj egzistencije tamo je čak izrijekom određen upravo u tom smislu. No stvar biva mnogo upitnijom kad Heidegger ustrajava na tomu da i drugom principu, dakle onom egzistirajućem, već samim tim da je i on određen kao volja, treba pripisati značaj poriva. U Schellinga je ono egzistirajuće bitno određeno razumom kao univerzalnom voljom. Heidegger pak nastoji pokazati da je i sam razum, u Schellinga označen kao »volja u volji«, u svojoj biti zapravo stremljenje i žudnja, premda ne na način slijepog poriva, nego kao znanje i na znanju utemeljeno htijenje:

»Htijenje je stremljenje i žuđenje, ali ne kao slijepi poriv i nagon, nego vođeno i određeno predodžbom onoga što se hoće. $\ll^{39}$

Da bi to pojasnio, upućuje na navlastitu djelatnost razuma, koju određuje kao »pred-očavanje «, $i$ to predočavanje jedinstva, kako je ta djelatnost $i$ inače bila shvaćana u cijeloj povijesti filozofije, naime kao » $\lambda o ́ \gamma o s$, sabiranje, izvorna sinteza $\ll{ }^{40}$ Bit tako shvaćena predočavanja prema Heideggeru je stalni i svakom konkretnom izvršenju prethodeći odnos spram sebe samog onog ja koje predočuje te time i hoće sama sebe. Predočavanje je uvijek »dostavljanje sebi onog pred-očenog te pripadanje $u$ to dostavljanje - a sve to u jedinstvu imanja sebe - (jastvo - kao sebstvo) «. ${ }^{41}$

Heidegger do tog tumačenja ne dolazi pukim apstraktnim domišljanjem. Pritom se stalno nastoji pozivati na Schellinga i strogo se držati njegova teksta. Da bi opravdao svoje shvaćanje da je voljno predočavanje u svojoj biti »volja donošenja sebe pred sebe, pred-očavanja sebe ${ }_{,}^{42}$ upušta se u krajnje istančanu interpretaciju važnog mjesta u spisu o slobodi na kojem se opisuje prvi pokret još tamnog temelja u smjeru egzistencije, pri čemu daje sjajan primjer svojega više nego dojmljivog umijeća tumačenja. U osloncu na formulaciju o Božjoj »refleksivnoj predodžbi« kojom se Schelling tamo služi, pokazuje da Bog u svojem pogledu usmjerenom prema temelju zapravo ugledava sama sebe, te na taj način, naime ukoliko gleda temelj, uistinu nalazi sama sebe kao pogledom osvijetljen temelj:

»U temelju - naime u svojoj žudnji, kao prvom pokrenutom pokretu - Bog sam vidi sebe kao onoga tko gleda, vidi sebe kao onoga tko sebe predočuje; jer, ukoliko neko predočavajuće donosi nešto pred sebe, ono sama sebe s tim zajedno stavlja u okružje onoga što stoji pred njim. « ${ }^{43}$

Tim istančanim tumačenjem biti razuma kao predočavanja - koje ostaje vrijediti za cijeli njegov misaoni put te u velikoj mjeri određuje i usmjerava njegovu sve oštriju kritiku biti tehnike kao »stavlja ${ }^{44}$ - Heidegger postiže to da sve što je izloženo u Schellingovu spisu o slobodi, dakle ne samo temelj egzistencije kao vlastitu volju nego i njemu suprotstavljeni princip univerzalne volje, a time i ljubav, duh, pa čak i samu slobodu, protumači kao momente jedinstvenog i sveobuhvatnog zbivanja u kojem apsolutna subjektivnost sebe samu htijuce jastvene volje bezuvjetno potvrđuje sebe. ${ }^{45}$ Cjelokupna interpretacija vrhuni se u zaključku da je htijenje u svim svojim vidovima pojavljivanja u osnovi uvijek isto htijenje sebe:

»Svako htijenje hoće sámo sebe. ${ }^{46}$

Dakle, razum, kojeg Schelling određuje kao univerzalnu, opću volju, Heidegger shvaća kao »pred-očavanje «, a ovo opet kao »subjektivnost $«{ }^{47} \mathrm{Kad}$ 
Schelling kao najvišu odredbu volje uz bestemeljnost i neovisnost o vremenu navodi potvrđivanje sama sebe, to bi prema Heideggeru trebalo shvatiti kao »htijenje sama sebe «. ${ }^{48}$ Odatle bi onda slijedilo da razum - Schellingova »volja u volji - nije drugo do »potvrđivanje sama sebe koje sámo sebe zna ${ }^{49}$ Sabere li se to sve, nadaje se zaključak da su volja temelja i volja razuma zapravo samo dva momenta jedinstvenog, jednom te istom voljom upravljanog zbivanja, bit kojega je »postajanje objavljenim, dovođenje sebe samome sebi, samobitak «. 50

$\mathrm{Na}$ osnovi te interpretacije Heideggeru onda nije bilo teško Schellinga bez ostatka uvrstiti u tisućljetnu predaju ne samo novovjekovne nego i, štoviše, cjelokupne zapadnjačke metafizike. U novovjekovnoj metafizici bitak je, neovisno o različitim imenima pod kojima nastupa, uvijek mišljen kao volja, i to u smislu poriva za ozbiljenjem egzistencije (exigentia essentiae), kako je to već u Leibniza mjerodavno došlo do izraza. ${ }^{51}$ Zato od vremena punog početka novog vijeka vrijedi opća odredba:

»Bitak bića je volja. Volja je sebe sa sobom uzimajuće sabiranje svakog ens k njemu samom. $\ll^{52}$

$\mathrm{Na}$ tako uspostavljenom temelju bitak kao volja može biti višestruko dalje mišljen, na primjer kao volja uma u Kanta, volja duha u Hegela, volja ljubavi u Schellinga, konačno volja za moći u Nietzschea kao zadnjeg velikog metafizičara..$^{53}$

38

M. Heidegger, Die Metaphysik des deutschen Idealismus, str. 87.

39

M. Heidegger, Schellings Abhandlung über das Wesen der menschlichen Freiheit (1809.), str. 114 (u GA 42, str. 164 manje odstupanje: »Htijenje je stremljenje za nečim i žudnja $(\ldots) \ll)$.

40

M. Heidegger, Die Metaphysik des deutschen Idealismus, str. 87.

41

Martin Heidegger, Seminare Hegel - Schelling, Peter Trawny (ur.), GA 86, Vittorio Klostermann, Frankfurt am Main 2011., str. 30. 42

Ibid., str. 152 (= GA 42, str. 219).

43

M. Heidegger, Schellings Abhandlung über das Wesen der menschlichen Freiheit (1809.), str. 151 (= GA 42, str. 218).

44

Usp. Martin Heidegger, »Wozu Dichter? «, u Holzwege, Friedrich-Wilhelm von Herrmann (ur.), GA 5, Vittorio Klostermann, Frankfurt am Main 1977., str. 288: »Nešto dovesti pred sebe na taj način da to ispred doneseno kao ranije predočeno određuje sve načine uspostavljanja u svakom pogledu temeljna je crta odnošenja koje poznajemo kao htijenje. Ovdje imenovano htijenje je us-postava, i to u smislu namjerne provedba opredmećivanja.«
45

Usp. M. Heidegger, »Schelling: Das Wesen der menschlichen Freiheit. Protokollheft aus dem WS 1927./28.«, str. 332. Usp. i str. 349.

46

M. Heidegger, Schellings Abhandlung über das Wesen der menschlichen Freiheit (1809.), str. 224.

47

M. Heidegger, Seminare Hegel - Schelling, str. 220.

48

M. Heidegger, Die Metaphysik des deutschen Idealismus, str. 88.

49

M. Heidegger, Seminare Hegel - Schelling, str. 253.

50

Martin Heidegger, Nietzsche II, Pfullingen 21961., str. 475.

51

Usp. Damir Barbarić, »Heideggers Leibnizauslegung«, u: Zum anderen Anfang, str. 97-112.

52

M. Heidegger, »Wozu Dichter?«, str. 278.

53

M. Heidegger, Nietzsche II, str. 452. Usp. Martin Heidegger, »Wer ist Nietzsches Zarathustra? «, u: Vorträge und Aufsätze, FriedrichWilhelm von Herrmann (ur.), GA 7, Vittorio Klostermann, Frankfurt am Main 2000., str. 113. 
Heidegger ide i dalje te tvrdi da to osnovno određenje bitka u smislu htijenja sebe, koje vrijedi za cijeli novi vijek, uključujući današnjicu, svoj izvor ima već u Grka. U cijeloj metafizici, kako grčkoj tako i onoj novovjekovnoj,

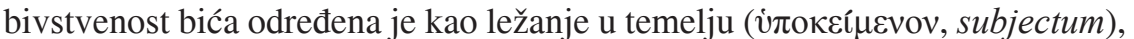
što znači kao subjektivnost, »i to na bezuvjetan način: htijenja sebe« ${ }^{54}$ Ako u dovršenju metafizike htijenje kao htijenje sebe u Hegela nastupa »kao dolaženje samom sebi te tako objavljivanje sebe i pojavljivanje pred samim sobom (apsolutna ideja)«, a u Nietzschea »kao nadilaženje sebe, kao premoćenje i zapovijed, 'volja za moći' «, Heidegger će Schellinga s njegovom osnovnom misli »bezuvjetne subjektivnosti kao 'ljubavi' smjestiti između njih dvojice, bez i najmanje naznake da bi ma i djelomice istupio, ili barem skrenuo s te jedinstvene putanje metafizike. ${ }^{55}$

Da bi se ta prosudba propitala treba prije svega pitati kako je u Schellinga uopće mišljena ljubav. Pritom se može poći od Heideggerova pogađajućeg uvida da za Schellinga ljubav nije pojedinačni fenomen, da nije tek jedno afektivno stanje ljudske osobnosti uz druga. Budući da je ona temelj svim ostalim sposobnostima i stanjima, može je se primjereno shvatiti jedino u punoj općenitosti, naime kao »smisao bitka, a to znači bitka osobe «. ${ }^{56} \mathrm{Hei}-$ degger ustvrđuje da je bit ljubavi, a time i duha i osobnosti, kojima ona leži u temelju, čisto povezivanje i sjedinjavanje. Ljubav je bezuvjetna spona oba principa živog bitka, temelja egzistiranja i onog egzistirajućeg. ${ }^{57}$ Ona je »ono izvorno i zapravo sjedinjujuće ${ }^{58}$ drugim riječima: $\gg$ ono svemu prethodno jedno (sjedinjujuće) $\ll .{ }^{59}$ Njezina bit je $» j e d n o t a \ll ~ o d n o s n o ~ » j e d i n s t v o \ll, ~ i ~ t o ~ » u$ smislu onog znajućeg - pred-očujući - voljnog - dakle otvorenog - pri samom sebi «. ${ }^{60}$ Utoliko je prema Heideggeru posve legitimno ljubav - dakako u smislu »ljubavi spram sama sebe« - protumačiti »kao bit samog bitka ${ }^{61}$ te u njoj spoznati najviše i najistinskije očitovanje volje:

»Pravo htijenje, pravo biće je ljubav.« ${ }^{62}$

Dakako, bilo bi pogrešno sjedinjavanje o kojem je tu riječ, dakle ono što bi trebalo biti sama bit ljubavi, a time i pra-bitka kao volje, shvaćati kao takvo koje se zadovoljava puko mirujućim jedinstvom te se, u slučaju da ga dostigne, i sámo smiruje i zaustavlja. Ako sjedinjujuća bit ljubavi počiva na identičnosti kao njezinoj najunutarnjijoj jezgri, ta identičnost ne smije se shvaćati kao apstraktna i mrtva, takva koja uvijek već postoji i u sebi nepomično stoji. Fascinirajuća živost Schellingove filozofije i njezina golema dinamičnost izviru upravo odatle što su u njoj volja, ljubav i bitak u cjelini neprestano gibani identičnošću koja se dade primjereno shvatiti i odrediti jedino kao »uzajamna pripadnost onog različitog ${ }^{6}{ }^{63}$ Ovdje se dakle radi o posve izvornoj identičnosti, onoj »koja kao takva povezuje ono različito i ono što može biti za sebe, držeći to jedno od drugog odvojenim «. ${ }^{64}$ I sam pra-bitak kao ljubeće htijenje nije drugo do »razlikovanost, sjedinjujuće odvajanje; bivanje « ${ }^{65}$

Iz toga slijedi da je, hoće li se spis o slobodi i tamo prikazana nečuvena drama božanskog i ljudskog bitka primjereno shvatiti, sve na tomu da se pred oči u svoj njezinoj silini i napetosti dovede ta čudesno protuobratna dvojnost u jedinstvu koja čini samu bit kako ljubavi tako i volje kao pra-bitka. Volja ljubavi - koja je kao bit bitka čak »najunutarnjija jezgra apsolutne slobode « ${ }^{66}$ - nije htijenje »bilo kakvog slijepog sjedinjavanja, samo da bi uopće bilo jedinstva, nego ona najprije i uistinu hoće odvajanje, ne da bi samo ostala pri njemu, nego da ostane temeljem za svaki put više sjedinjavanje $\ll .{ }^{67}$ Heidegger prodorno i uvjerljivo interpretira teška, jedva razrješiva mjesta spisa o slobodi na kojima biva prikazano sebi samom protivno i sebe uvijek iznova nadilaze- 
će bivanje, koje objašnjava kao neprestano izlijevanje ljubeće volje, koja se od sebe odvaja te se istovremeno sjedinjuje sa sobom samom i s onim što joj je suprotstavljeno. Svaki od dvaju principa, naime temelj i ono egzistirajuće, ljubavlju su potaknuti i tako reći natjerani htjeti same sebe, ali svagda na taj način da svaki od njih hoće ono njemu suprotstavljeno, da bi se u tomu opet vratio sebi, no svaki put na višem stupnju:

»Temelj tako hoće biti sve više temelj, a ujedno to može htjeti samo time da ujedno hoće i ono svjetlije te tako stremi protiv sebe kao tamnog, time dakle da stremi za protivnošću sama sebe i tako u sebi rađa udvajanje. Što temeljnije (u temelj stremeće), a ujedno i svaki put svjetlije (sjedinjavanju stremeće) biva udvajanje, to više se jedno od drugog udaljuju oni razdvojeni, temelj i egzistencija; ali to dublje iz temelja dolazi ono sjedinjavajuće i to više sjedinjavanje stremi u svjetlo, to odriješenijom biva sveza, to bogatijom biva mnogostrukost onih povezanih. (...) Što je protivnije jedinstvo onog bivajućeg, što je stvaralačkije ono stvaralačko, to više ono gubi neodređenost bezmjernog, nepravilnog nagona. Što je sebičnije bivanje, to je svjetlije i više zajedničko ono što je od njega nastalo; ali sebičnost raste upravo s postajanjem temelja svijetlim. Stoga je u tom u sebi protivnom bivanju stalno nadmašivanje i stremljenje prema vani i prema gore u stupnjeve koji su sve viši. $\ll^{68}$

Heidegger, dakle, ljubav vidi kao središte spisa o slobodi. Ljubavlju biva tamni, u sebe zatvoreni temelj nagnan otvoriti se svjetlu i općoj volji te stremiti prema gore, kao što, obratno, onaj po sebi samom sebi dovoljni i ravnodušni netemelj istom tom ljubavlju biva potaknut priječi u egzistenciju, to znači u »objavljenost, donošenje sebe samom sebi, samobitak u samobivanju protiv temelja i njemu nasuprot «. ${ }^{69}$ Heidegger tu najizvorniju, samu sebe htijuću ljubav - ne bez prešutnog pogleda spram Nietzschea - određuje kao najvišu moć, kojoj uspijeva čak ono naoko nemoguće, naime »ono drugo dovesti sebi i pustiti da stoji u sebi te tako na tomu suprotnost dovesti u bivstvo; tek tako ‘jednotu' za sebe utemeljiti u bivstvu i dovesti je u objavljenost « ${ }^{70}$

54

M. Heidegger, Die Metaphysik des deutschen Idealismus, str. 90

55

M. Heidegger, Schellings Abhandlung über das Wesen der menschlichen Freiheit (1809.), str. 224.

56

M. Heidegger, »Schelling: Das Wesen der menschlichen Freiheit. Protokollheft aus dem WS 1927./28.«, str. 352.

57

M. Heidegger, Seminare Hegel - Schelling, str. 223.

58

M. Heidegger, Schellings Abhandlung über das Wesen der menschlichen Freiheit (1809.), str. 154 (= GA 42, str. 222).

59

M. Heidegger, Seminare Hegel - Schelling, str. 241.

60

Ibid., str. 246

61

M. Heidegger, Schellings Abhandlung über das Wesen der menschlichen Freiheit (1809.), str. 193 (= GA 42, str. 277).
62

M. Heidegger, Die Metaphysik des deutschen Idealismus, str. 90

63

M. Heidegger, Schellings Abhandlung über das Wesen der menschlichen Freiheit (1809.), str. 126 (= GA 42, str. 183).

64

Ibid., str. 154 (GA 42, str. 222).

65

M. Heidegger, Die Metaphysik des deutschen Idealismus, str. 97.

66

M. Heidegger, Schellings Abhandlung über das Wesen der menschlichen Freiheit (1809.), str. 193 (= GA 42, str. 277).

67

Ibid., str. 154 (= GA 42, str. 222 i d.).

68

Ibid., str. 164 (= GA 42, str. 236 i d.).

69

M. Heidegger, Nietzsche II, str. 475.

70

M. Heidegger, Die Metaphysik des deutschen Idealismus, str. 185. 
Ima li se sve to na umu, čini se da uobičajeni nazor prema kojem je Heideggerova interpretacija Schellingova spisa o slobodi u osnovi »metafizika zla« bitno promašuje stvar. ${ }^{71}$ Heidegger se, doduše, nerijetko izražava baš u tom smislu, a u tijeku interpretacije često se može činiti da je problem zla isturen u njezino pročelje. Međutim, u punoj suglasnosti sa Schellingom on ustrajava na tomu da je najviši smisao zla pružanje konačnog dokaza vječne svemoći ljubavi:

»Zašto se uopće baviti zlom? Zato što ono proizvodi najunutrašnjiji i najveći razdor u biću. Ali zašto upravo razdor? O zlu se misli jer se u tom krajnjem i pravom razdoru kao ne-sklopu ujedno mora najoštrije pokazati jedinstvo sklopa bića u cjelini. «72

Odatle je razvidno da njegova objašnjenja mogućnosti, zbiljnosti i svrhe zla, koja nesporno pogađaju Schellingove prave nakane, nisu najviše i najvažnije postignuće njegova tumačenja spisa. Glavni ishod i ono najsvojstvenije njegove interpretacije sastoji se u nečemu drugom, u tomu naime da je u njoj bitak kao htijenje poistovjećen s ljubavlju, a ova opet s posve široko shvaćenim porivom, u smislu htijenja sama sebe.

Međutim, taj bitni i najvažniji ishod Heideggerove interpretacije postaje krajnje upitan biva li suočen s onim što sam Schelling na koncu spisa naglašeno i nedvosmisleno označava onim najvišim cjelokupnog istraživanja, nastojeći to barem donekle približiti pomoću poprilično zagonetnih imena »indiferencije i »netemelja«, koja stvar o kojoj se tu radi više naznačuju nego što bi je točnije određivala. Razumljivo je da je taj vrhunac istraživanja u spisu, koji je oduvijek križ svih interpreta, odmah u početku privukao Heideggerovu najveću pozornost. Mjesta u tekstu koja se na to odnose on iscrpno navodi i uvijek iznova nastoji u zagonetno, teško razmrsivo klupko višeznačnih nagovještaja unijeti barem nešto svjetla razumijevanja. Dobro uočava da tom tajnovitom indiferencijom, koja prethodi kako temelju tako i onom egzistirajućem, koja dakle nije nijedno od to dvoje, ali nije ni nekakav njihov spoj ili mješavina, cijela njegova interpretacija biva podignuta na višu i zahtjevniju razinu, na kojoj će mu se sve dotad postignuto pokazati iz temelja upitnim: »S indiferencijom se mora postupati apsolutno ozbiljno. « ${ }^{73}$

To zahtijevano ozbiljno postupanje ne može značiti ništa manje od zadaće da se jasno uoče i misleći proslijede sve posljedice činjenice da Schelling indiferenciju određuje kao »vlastito, od svake suprotnosti odijeljeno biće ${ }^{74}$ te povrh toga tvrdi da ljubavi u indiferenciji nema. ${ }^{75} \mathrm{Kad}$ Schelling objašnjava - što Heidegger također navodi ${ }^{76}$ - da se netemelj, koji je po sebi ravnodušan, dijeli samo radi toga da bi bilo života i ljubavi, ${ }^{77}$ iz toga nedvosmisleno slijedi da ljubav za Schellinga nije ono prvo i najviše, kako to Heidegger tumači, polažući taj stav u osnovu cijele svoje interpretacije. Oba nosiva stupa njegove interpretacije kolebaju se dakle i lome pod težinom riječĩ samog Schellinga. Jer ovaj posve izričito kaže da netemelj kao indiferencija nije identičnost, kao i to da u netemelju odnosno indiferenciji nema ljubavi.

Sve govori u prilog tomu da je Heidegger tu naišao na granicu koju nije bio spreman prekoračiti. Ne obrazlažući dalje, on nasuprot Schellingovoj izričitoj tvrdnji ustrajava na stavu da je »apsolutna indiferencija (apsolutni netemelj) kao ljubav još prije diobe temelja i egzistencije $\ll{ }^{78} \mathrm{Na}$ osnovi te interpretativne odluke može onda odustati od vlastita u početku izlaganja postavljenog zahtjeva da se indiferencija uzme posve ozbiljno. Osobito u prvom tematskom suočenju sa Schellingovim spisom o slobodi, u seminaru i vježbama iz 1927./28., početno se s punom strašću mišljenja upustio u problem indiferencije odnosno netemelja, da bi ubrzo od toga odustao, uz rezigniranu napomenu da se tu »apstraktno-formalno (jednostavno na osnovi Schellingovih termino- 
loških određenja) ne dospijeva dalje«, pri čemu mu se čak postavilo pitanje »postoji li, vrati li se natrag na netemelj, uopće neki opravdani odnosno legitimni problem $\ll .{ }^{79} \mathrm{U}$ indiferenciji se, jer joj ne pridolazi nijedan predikat, ne može vidjeti ništa više od »ideje nečeg naprosto iščezlog « ${ }^{80}$ Premda je voljan priznati da je Schellingova ideja identičnosti i netemelja kao in-diferencije u usporedbi s Hegelom »izvornija«, za Heideggera ipak i ona ostaje »unutar apsolutne metafizike subjektivnosti «, i to kao »puko od-reknuće «. ${ }^{81} \mathrm{Iz}$ vlastite prosudbe da u Schellinga još uvijek vladajućim ostaje »osnovni stav subjektivnosti« on izvlači konačan zaključak: »I ovdje isto temeljno držanje kao i Hegel. $\ll^{82}$

To bitno kritičko odbacivanje, koje je unatoč svem uvažavanju zadnji ishod Heideggerova opetovanog suočavanja sa Schellingom, uistinu je odbacivanje slobode kao indiferencije kako ju je mislio Schelling. U pismu Jaspersu od 17. kolovoza 1949. Heidegger priznaje:

»Ne samo Schellingova 'indiferencija' i svi drugi govorni obrati 'idealista', također i mistika u njezinom slikovnom bjesnilu, koje uvijek kazuje isto, čini mi se velikim zavođenjem: pobjeći

71

Usp. na primjer Thomas Buchheim, »Schelling und die metaphysische Zelebration des Bösen«, Philosophisches Jahrbuch 107 (2000), str. 47-60; Thomas Buchheim, »Metaphysische Notwendigkeit des Bösen. Über eine Zweideutigkeit in Heideggers Auslegung der Freiheitsschrift«, u: István M. Fehér, Wilhelm G. Jacobs (ur.), Zeit und Freiheit. Schelling - Schopenhauer-Kierkegaard - Heidegger, Budimpešta 1999., str. 183-191; Sebastian Kaufmann, »Metaphysik des Bösen - Zu Heideggers Auslegung von Schellings Freiheitsschrift«, u: Heideggers Schelling Seminar (1927./28.). Die Protokolle von Martin Heideggers Seminar zu Schellings 'Freiheitsschrift' (1927./28.) und die Akten des Internationalen Schelling-Tags 2006. Lektüren F. W. J. Schellings I, str. 193 226 (osob. str. 207 i d.).

72

M. Heidegger, Schellings Abhandlung über das Wesen der menschlichen Freiheit (1809.), str. 216.

73

M. Heidegger, »Schelling: Das Wesen der menschlichen Freiheit. Protokollheft aus dem WS 1927./28.«, str. 338.

74

Friedrich Wilhelm Joseph Schelling, Philosophische Untersuchungen über das Wesen der menschlichen Freiheit und die damit zusammenhängenden Gegenstände, u: Sämmtliche Werke, Karl Friedrich August Schelling (ur.), sv. VII, J. G. Cotta, Stuttgart; Augsburg 1860. (dalje se navodi kao SW VII), str. 407; Friedrich Wilhelm Joseph Schelling, Philosophische Untersuchungen über das Wesen der menschlichen Freiheit und die damit zusammenhängenden Gegenstände, u: Historisch-kritische Ausgabe. Im Auftrag der Bayerischen Akademie der Wissenschaften,
Thomas Buchheim et al. (ur.), frommannholzboog, Stuttgart-Bad Cannstatt 1976. i d., sv. 17, Christoph Binkelmann et al. (ur.), Stuttgart 2018. (dalje se navodi kao AA 17), str. 171 .

75

F. W. J. Schelling, SW VII, str. 408 (= AA 17, str. 172): »Denn die Liebe ist weder in der Indifferenz (...).«

76

M. Heidegger, »Schelling: Das Wesen der menschlichen Freiheit. Protokollheft aus dem WS 1927./28.«, str. 339.

77

F. W. J. Schelling, Philosophische Untersuchungen über das Wesen der menschlichen Freiheit und die damit zusammenhängenden Gegenstände, SW VII, str. 408 (= AA 17, str. 172).

78

M. Heidegger, Seminare Hegel - Schelling, str. 241. Isticanje Heideggerovo. Usp. i str. 260.

79

M. Heidegger, »Schelling: Das Wesen der menschlichen Freiheit. Protokollheft aus dem WS 1927./28.«, str. 340.

80 Ibid., str. 339.

81

M. Heidegger, Schellings Abhandlung über das Wesen der menschlichen Freiheit (1809.), str. 234

82

M. Heidegger, Seminare Hegel - Schelling, str. 260. 
odavde iz svijeta i od ljudi i od prijatelja - a za uzvrat - ako to uopće uspije - ne dati ništa do beskonačno svjetlo, neispunjiv bezdan. ${ }^{83}$

Heideggeru, dakle, nije uspjelo u Schellingovoj »indiferenciji« prepoznati neki jasan i uvjerljiv filozofijski smisao. Kako je već rečeno, jedini pravi, bez zadrške i predrasuda izvedeni pokušaj poimanja indiferencije poduzeo je 1927./28. pri svojem prvom suočenju sa spisom o slobodi. ${ }^{84}$ Tamo je odmah ustvrdio da netemelj odnosno indiferenciju treba shvaćati »ne kao nedostatak - nego kao otključano bogatstvo $\ll{ }^{85}$ Međutim, kad je u nastavku to bogatstvo pokušao konkretno odrediti i mišlju njime ovladati, naišao je na proturječje koje mu se učinilo tako nesavladivim da, kako sam priznaje, nije dospio dalje. Ono što ga je zaustavilo bilo je to da Schelling indiferenciji izrijekom odriče sve predikate, ali ipak barem posredno spominje svojstvenu joj »dvoznačnost«. To ga je potaknulo na odlučujuće i zacijelo opravdano pitanje, iz kojeg se kao sam od sebe razvio tijek misli koji je za naše razmatranje od najveće važnosti te ga stoga vrijedi u cjelini navesti:

»Gdje je još uopće moguća dvoznačnost unutar apsolutne indiferencije? 'Ovo kao i ono' izraz je za dvoznačnost, tako da izgleda kao da Schelling netemelj ovdje shvaća onako kako ga sam odbija shvatiti. Ako je sve 'iščezlo', onda vrijedi 'niti-niti'; ali u tomu je još neki zadnji pogled unatrag na iščezavanje. U slučaju 'dvoznačnosti' zapravo se ne može tako apsolutno govoriti o iščezlosti. Schelling ovdje ne razlikuje dovoljno oštro između 'ovo kao i ono' $i$ 'niti-niti'. U tom udvostručenju unutar netemelja kao iščezlog, ali ipak još uznemirujućeg, leži stanovito pravo govoriti o ‘dvoznačnosti' onog bivstva koje je pra-bitak, to znači htijenje, poriv. ${ }^{86}$

Pogleda li se, imajući na umu ovu najdublju dolaznu točku Heideggerove interpretacije, s punom pozornošću sam Schellingov tekst, biva vidljivo da odnos indiferencije spram oba principa, temelja i onog egzistirajućeg, tamo nije određen tek negativno, dakle ne jedino time da u indiferenciji nije nijedan od njih kao takav. Bitno ja da Schelling dopušta da indiferencija jednako tako može i biti oba ta principa, dakako ne ujedno, nego uvijek odvojeno, naime tako da u svakom od njih uvijek bude cijela. Stoga nije dovoljno odnos dvaju principa spram netemelja odnosno indiferencije shvaćati samo negativno, kao »niti-niti«, nego ga se povrh toga mora shvatiti i pozitivno, to znači kao »ovo kao i ono«. S obzirom na to, Heideggerovo se tumačenje indiferencije kao čistog iščezavanja ispostavlja kao bitno prikraćeno i jednostrano. Promiče mu da Schelling izričito tvrdi da »iz niti-niti, odnosno indiferencije« dvojnost principa zapravo $»$ neposredno proizlazi $\ll{ }^{87}$ Time biva otvoren put za poimanje indiferencije kao siromaštva i posvemašnjeg nedostajanja odredbi, ali jednako tako i kao punine i preobilja, dakle upravo kao »otključanog bogatstva«, kako je sam Heidegger to u početku predmnijevao. ${ }^{88}$

Taj je put tumačenja Heidegger međutim ostavio zatvorenim. U naoko posve paradoksalnom »udvostručenju « indiferencije, u tomu naime da je ona »niti-niti«, a jednako tako i »ovo kao i ono«, nije razabrao drugo do Schellingovu navodnu nesposobnost oštrog lučenja i razlikovanja. ${ }^{89} \mathrm{I}$ kasnije će, u jednoj bilješci iz okružja svojega drugog predavanja o spisu o slobodi, ostati pri istom prigovoru:

»Nema figuracije jednote netemelja, a to znači 'onog nadbićevnog'.«90

Jedino pozitivno za što mu se činilo da još može nazrijeti u toj iritirajućoj neodređenosti indiferencije Heidegger je naznačio gotovo usputnom napomenom da iščeznuće svih predikata koje Schelling ustvrđuje ipak nije apsolutno. Jer, kako smo već čuli, »neki zadnji pogled unatrag na iščezavanje « u indiferenciji čuva još u sebi snagu uznemiravanja koja sama ne iščezava. Upravo to, kako se čini, dopušta da se indiferencija odredi kao pra-bitak, a ovaj opet kao 
htijenje, to znači kao poriv i ljubav. U tom suptilnom i zamršenom promišljanju stječe se Heideggerova najviša, u sebi dvostruka interpretativna odluka, koja je s jedne strane odluka o oproštaju od indiferencije po sebi, koju i sam Schelling ostavlja u tajnovitoj neodređenosti, a s druge, s tim ujedno, o tomu da indiferenciju sa svoje strane protumači kao ljubav koja zna i hoće, to znači kao poriv za predočavajućim htijenjem i potvrđivanjem sebe. Odatle biva shvatljivo to da Heidegger naposljetku čak i slobodu proglašava onim što počiva na ljubavi - i to kao ljubavi spram sama sebe - i iz nje izvire. Takva je ljubav za njega upravo »najunutarnjija jezgra apsolutne slobode «. ${ }^{1}$

Sve to u osnovi promašuje ne samo slovo Schellingove rasprave nego i njezinu najvišu nakanu. Kako je rečeno, Schelling apsolutnu indiferenciju jednoznačno označava onim najvišim cijelog svojeg istraživanja. Ljubav je za njega samo način kako se indiferencija u životu i bivanju može pojaviti, ona je tako reći njezin porod i izljev, međutim takav koji se pojavljuje tek $n a-$ kon što se indiferencija udvojila u dva jednako izvorna, samostalna i za sebe

83

M. Heidegger, Karl Jaspers, Briefwechsel 1920. - 1963., str. 184.

84

$\mathrm{U}$ interpretaciji spisa o slobodi u predavanjima iz 1936. Schellingov »netemelj« više nije tematiziran, što vjerojatno ima razloge sustavne naravi. Usp. uz to iscrpno Ryôsuke Ohashi, »Der Ungrund und das System «, u: Otfried Höffe, Annemarie Pieper (ur.), Friedrich Wilhelm Joseph Schelling, Über das Wesen der menschlichen Freiheit (Klassiker Auslegen, sv. 3), Akademie Verlag, Berlin 1995., str. 235-252, osob. str. 148: »Ponovno upada u oči da Heidegger ovdje (...) 'netemelj' uopće nema u oku i da on u njegovu prebolijevanju metafizike ne igra nikakvu ulogu. To se dade svesti na to da je Heidegger raspravu o slobodi izlagao posve i samo s obzirom na metafizički bitkovni sklop temelja i egzistencije, dok 'netemelj' nije ni Bog ni biće, te tako više ne pripada onto-teologiji odnosno metafizici. Heidegger ga nije previdio slučajno, nego upravo zbog vlastita mislilačkog smjera gledanja.«

85

M. Heidegger, Seminare Hegel - Schelling, str. 241.

86

M. Heidegger, »Schelling: Das Wesen der menschlichen Freiheit. Protokollheft aus dem WS 1927./28.«, str. 342

87

F. W. J. Schelling, Philosophische Untersuchungen über das Wesen der menschlichen Freiheit und die damit zusammenhängenden Gegenstände, AA 17, str. 171 (= SW VII, str. 408).

88

Kako je pokazala Lore Hühn, »Der Wille, der Nichts will. Zum Paradox negativer Freiheit bei Schelling und Schopenhauer«, u: Lore
Hühn (ur.), Die Ethik Arthur Schopenhauers im Ausgang vom Deutschen Idealismus (Fichte/Schelling), Ergon Verlag, Würzburg 2006. str. 149-160, osob. str. 155 i d., bit »ekstaze«, kako je misli Schelling, u iskustvu je punine bezvremene sve-prisutnosti u onomu što se zbog svoje čistoće lišene svakog određenja početno pokazuje kao ništa. Schopenhauera s njegovim naučavanjem o samoukidanju volje može se u tom pogledu smatrati Schellingovim sljedbenikom. U tom sklopu naznačen odnos spram kršćanskog nauka o conversio (str. 157 i d.) zacijelo je vrijedan daljnjeg promišljanja. Za temu usp. Jörg Ewertowski, Die Freiheit des Anfangs und das Gesetz des Werdens. Zur Metaphorik von Mangel und Fülle in F. W. J. Schellings Prinzip des Schöpferischen, frommann-holzboog, Stuttgart-Bad Cannstatt 1999., osob. str. 267 i d.

89

Heidegger u svojim vježbama uz Schellingovu negativnu i pozitivnu filozofiju (M Heidegger, Seminare (Übungen) 1937./38. und 1941./42.: 1. Die metaphysischen Grundstellungen des abendländischen Denkens; 2. Einübung in das philosophische Denken, str. 140) vlastitu nedoumicu u pogledu Schellingove apsolutne indiferencije pripisuje samom Schellingu. Premda smatra vrijednim priznanja to da se Schelling ne zadovoljava uzajamnom dijalektikom inteligencije i prirode, »već poseže unatrag u temelj obih kao apsolutnu indiferenciju«, ipak mu se čini da Schelling ovdje dospijeva »u najveću teškoću«, koja se sastoji u tomu da »ono što zapravo pozitivno misli mora reći čisto negativno«.

90

M. Heidegger, Die Metaphysik des deutschen Idealismus, str. 93.

91

M. Heidegger, Schellings Abhandlung über das Wesen der menschlichen Freiheit (1809.), str. 193 (= GA 42, str. 277). 
odvojena principa. Jedno od Schellingovih imena za apsolutnu indiferenciju kakva je po sebi, prije te diobe, glasi »nehtijuća volja«, odnosno »volja koja neće ništa«. Njezino potomstvo, tako reći njezin trag i namjesništvo u zbiljskom svijetu dvaju suprotstavljenih principa, dakle živog bivanja, upravo je ljubav, ali - a to je odlučujuće - takva koja neće svoje i vlastito. Oboje, kako nehtijuću volju tako i ljubav koja neće ono vlastito, Heidegger ostavlja jedva spomenutim na rubu svoje interpretacije. A kad povremeno ipak dođe do toga da bi ljubav koja neće svoje bila vrijedna spomena, određuje je naprosto kao »bezuvjetnu subjektivnost «.92

On doduše poznaje, pa čak i više puta spominje Schellingovo određenje čiste volje kao takve koja neće ništa te je zato »opuštena prisnost «. ${ }^{93}$ Međutim, da bi dokazao unutarnju proturječnost tog pojma, a stoga i zbiljsku nemogućnost onoga što bi njime trebalo biti mišljeno, napominje da volja po svojoj biti uvijek hoće samu sebe, »jer čak i kad neće ništa, ipak hoće samu sebe: volju «. ${ }^{94}$ I kad u nastavku prenosi Schellingovu znakovitu napomenu da je za volju upravo ne-htijenje »ono najteže i nepojmljivo« jer ono ne bi značilo drugo do »ukidanje sama sebe žrtvovanjem svojega sebstva «, ${ }^{95}$ ne pada mu na pamet propitati mogućnost da je Schelling svojim spisom o slobodi možda smjerao upravo na takvo ukidanje sebe.

A ipak mu se to moglo i trebalo pokazati vjerojatnim, ako ni zbog čega drugog, onda na osnovi Schellingovih škrtih, ali značajnih nagovještaja o tajnovitom »središtu«, u kojem »u sjaju božanskog svijetlog pogleda [prebiva] najčistija bit sve volje«, zbog čega je taj pogled »za svaku pojedinačnu volju sažižuća vatra.$^{96}$ Umjesto da tu naznaku dovede u vezu sa Schellingovim često ponavljanim govorom o čistoj volji kao nehtijućoj, te da odatle izvuče zaključak o zbiljskom i pozitivnom postojanju te navodno paradoksalne i proturječne volje, Heidegger se radije odlučuje to »središte« kao »najčistiju bit volje« bez daljnjeg obrazloženja poistovjetiti s Leibnizovim »Ens entium, ens summum, causa realis $\ll .{ }^{97}$

Tako je u Heideggerovoj interpretaciji Schellingova spisa jedna njegova bitna, čak odlučujuća dimenzija ostala po strani. Budući da je ljubav tu shvaćena i protumačena jednostrano, samo u smislu htijenja i potvrđivanja sama sebe, odricanje od onoga svojeg i vlastitog, tako bitno za Schellingov pojam ljubavi, ostalo je van okvira interpretacije. Kad Heidegger jednom zgodom navodi Schellingov stav iz Razdoblja svijeta da je ljubav ništa vlastitosti te ne traži ono njezino, zbog čega od same sebe niti ne može biti bićem, on u tomu ne uspijeva razabrati ništa pozitivno, već odatle samo zaključuje na u tomu impliciranu sebe-zatvarajuću temeljnu crtu bitka. ${ }^{98}$ Ili kad drugom zgodom spominje Schellingov u Erlangenškim predavanjima izloženi stav da vječna sloboda ne može biti to što ona jest, jer bi se u tom slučaju morala zatvoriti i ograničiti u određeni lik te više ne bi bila apsolutna sloboda, ${ }^{99}$ on to doduše povezuje $\mathrm{s}$ »čistom voljom, koja niti hoće niti neće - ravnodušnošću - 'indiferencijom' «, ali i tu teškoću rješava tako da ono o čemu je tu riječ tumači kao »vječnu možnost - kao znanje, kao htijenje učinka «. ${ }^{100}$

Jedna od značajnih posljedica te interpretacije u kojoj indiferencija, kao apsolutno slobodna, a to znači nehtijuća volja, biva pretumačena u porivom vođeno htijenje sama sebe, je i upadljivo ontologijsko depotenciranje duše, kojoj je Schelling već u spisu o slobodi, a onda osobito u vrijeme neposredno nakon njega, prije svega u Stuttgartskim privatnim predavanjima i u dijalogu Kla$r a$, pridao iznimno važnu ulogu. I u ovom slučaju Heidegger najprije navodi Schellingov u Stuttgartskim privatnim predavanjima izloženi nazor da je duša »ono pravo božansko u čovjeku, dakle ono neosobno, pravo biće, kojemu ono 
osobno kao nebiće treba biti podvrgnuto «, ${ }^{101}$ ali ujedno propušta čuti u tomu sadržanu osnovnu postavku da je duša, kao ona koja posreduje božansku dobrotu, nadređena svakoj osobnosti, a to znači kako duhu tako i samoj ljubavi kao njegovoj biti. On tomu nasuprot dušu određuje kao podložnu duhu, kojeg vidi kao jedinu »izvorno sjedinjujuću jednotu «, ${ }^{102}$ te je zatim, oslanjajući se na Schellingovu ranu filozofiju prirode, u obzir uzima isključivo kao svezu koja sjedinjuje temelj i egzistenciju te ih drži zajedno. Tomu međutim dodaje da ona kao takva veza ipak ostaje »u temelju«, to znači »uvezana u ono jedinstveno pojedinačno«, te zato pripada samo području prirode, koja je »još lišena govora, ali sebe razvija u raščlanjenu i u sebe uigranu mnogostrukost likova ${ }^{103}$

$$
* * *
$$

Heidegger se, dakle, od Schellinga oprostio ne našavši očekivanu potporu za svoj vlastiti filozofijski pothvat. Niti jedno drugo Schellingovo djelo nije tako temeljito studirao i tako prodorno tumačio kao spis o slobodi. Ako ponekad i spominje Schellingova Stuttgartska privatna predavanja, ili ulomak Razdoblja svijeta, ili pak - uvijek samo ovlašno i usput - takozvanu pozitivnu filozofiju, nema se dojam da to počiva na temeljitoj lektiri, a pogotovo na sumislećem i zbilja prisvajajućem promišljanju. U misaonom suočenju sa Schellingom on je, slično kao u slučaju Nietzschea, previdio ili marginalizirao mnogo toga na što se inače u vlastitu mišljenju mogao osloniti. Početno nešto suzdržanija tendencija da Schellingovo cjelokupno djelo proglasi pripadnim zapadnjačkoj metafizici subjektivnosti, a to znači volje, s vremenom je postajala sve snažnijom i naposljetku se prometnula u jedinu nit vodilju shvaćanja i tumačenja. Tako je Heidegger svojim putom išao dalje bez Schellinga, ne znajući, a možda i ne sluteći u kolikoj mjeri je njegovo vlastito kasno mišljenje blisko Schellingovu. Da bi se ta bliskost pokazala, bilo bi potrebno interpretativno prikazati najvažnija djela i problemska okružja obojice mislilaca, najprije svako za sebe, a onda i u njihovu uzajamnom odnosu, što je ovdje nemoguće. Stoga se ograničavamo na to da samo na način teza i bez

92

Ibid., str. 224. Tako i M. Heidegger, Die Metaphysik des deutschen Idealismus, str. 101, gdje je noseća riječ znakovito kurzivom istaknuta i stavljena među znakove navoda: »ljubav«.

93

M. Heidegger, Die Metaphysik des deutschen Idealismus, str. 102.

94

Ibid., str. 107.

95

Ibid.

96

M. Heidegger, Schellings Abhandlung über das Wesen der menschlichen Freiheit (1809.), str. 183 (= GA 42, str. 263).

97

Ibid., str. 211
98

M. Heidegger, Die Metaphysik des deutschen Idealismus, str. 93.

99

M. Heidegger, Seminare Hegel - Schelling, str. 525

100

Ibid., str. 525. Podcrtavanje Heideggerovo.

101

M. Heidegger, Die Metaphysik des deutschen Idealismus, str. 135.

102

M. Heidegger, Schellings Abhandlung über das Wesen der menschlichen Freiheit (1809.), str. 154 (= GA 42, str. 222).

103

Ibid., str. 160 (= GA 42, str. 231). 
inače nužnog izvođenja i obrazlaganja ukažemo na neke od bitnih srodnosti u njihovu djelu.

Kako je već rečeno, Heidegger u Schellinga nije našao vlastitu vodeću misao konačnog bitka. Po njegovu mišljenju, Schelling ono najviše, sámo ono apsolutno, misli naprosto kao beskonačno. Je li doista tako? I kako je beskonačnost u Schellinga zapravo određena?

Premda Schelling u sklopu raspravljanja o apsolutnoj indiferenciji ponekad rabi riječ »beskonačno«, potrebno je svaki put što točnije odrediti što je pod tim izrazom u dotičnom kontekstu uistinu mišljeno. Tada bi moglo postati očitim da je »ono apsolutno《 za Schellinga isto što i netemelj odnosno apsolutna sloboda, a ova pak da je isto što i apsolutna indiferencija. Apsolutnost, koja označava ono svagda isto što se krije pod tim različitim imenima, sastoji se upravo u tomu da se ne bude ništa određeno te time i konačno. Stoga se može činiti da apsolutnost, slobodna od svake određenosti, uključujući i onu bitka, iščezava u nekoj nadbićevnoj i stoga beskonačnoj onostranosti. Upravo tako, naime kao čisto iščezavanje, pokazala se apsolutna indiferencija Heideggeru, koji je međutim, kako smo čuli, ipak u dvoznačnosti koju joj Schelling pripisuje naslutio jedva zamjetni trag nekog prvog pokreta u smjeru određenja, a time i određene bićevnosti, premda tu slutnju nije produktivno preuzeo u razvijanje svoje interpretacije.

Da je to mogao i čak trebao učiniti postaje jasno iz Schellingovih kasnijih promišljanja, koja se nastavljaju na tu najvišu točku spisa o slobodi, a izložena su prije svega u ulomcima i nacrtima za Razdoblja svijeta te u Erlangenškim predavanjima. Tamo se on s najvećim žarom zrelog mišljenja upušta u to da što potpunije razvije i izloži svoju središnju temu vječne slobode kao apsolutne indiferencije. Ovdje se ograničavamo na predavanja održana u Erlangenu, točnije na uvodno predavanje, u filozofovim Sabranim djelima objavljeno pod naslovom »O naravi filozofije kao znanosti«, vjerojatno jedino koje je Heidegger tada mogao poznavati.

Apsolutnu indiferenciju tamo susrećemo pod imenom »apsolutnog subjekta«, takvog koji kroz sve prolazi, a nije ni u čemu, naime nije tako da ne bi mogao biti i drukčije. U skladu s onim o čemu je tu riječ, Schelling se tu izražava krajnje sažeto: »Nema ničega što bi to bilo i nema ničega što to ne bi bilo«; upravo zato je to »ono incoercible, ono neshvatljivo, istinski beskonačno«. ${ }^{104}$ Prvenstveno mu je do toga da pokaže da ispravno mišljeni i razvijeni pojam apsolutne indiferencije nije samo negativan, već naprotiv u punom smislu pozitivan. Jer apsolutna indiferencija »je ništa - ne nešto, a čak bi i to bila u najmanju ruku neka negativna definicija; ali to [naime, apsolutna indiferencija] također nije neko ništa, to znači da je sve «. ${ }^{105}$ Dakle, ono bitno u tomu nije to da apsolutna indiferencija ne prihvaća nikakvu određenost, nego to da svaku određenost može i prihvatiti i ne prihvatiti. Biva li kao potpuna ravnodušnost do kraja promišljena, postaje jasno da je potpuno slobodna $» u$ neki lik se uključiti i ne uključiti«, tako da je jedino primjereno reći da je ona »ravnodušnost koja ponovno uključuje samu sebe i neravnodušnost «. ${ }^{106}$

Očito je da se u onomu što Schelling ovdje razlaže, a što osim imenima »vječne slobode « $\mathrm{i}$ »potpune ravnodušnosti odnosno indiferencije « biva nazvano i imenom »mirujuće odnosno čiste volje«, krije nešto što je misli konačnosti bitka, vodećoj misli Heideggerove filozofije, bliže nego je to on mogao i htio opaziti. ${ }^{107}$ Potpuna indiferencija je bez ikakve određenosti, ali ne tako da ne bi mogla biti i određena. Zato je Schelling označava i kao »vječnu, čistu možnost«, čija se apsolutnost sastoji u tomu da je »možnost radi možnosti, možnost lišena namjere i predmeta «. ${ }^{108}$ Ili drukčije rečeno, vječna odnosno 
apsolutna sloboda nije samo slobodna od sve određenosti, a time i konačnosti, nego je bitno slobodna i od same sebe kao takve slobode te stoga slobodna ući u konačnost. ${ }^{109}$

Ta dvostrukost, ta unutarnja protuobratna pokretnost sebe-ustežućeg odvraćanja i istovremeno navraćujućeg prilaženja svojstvena je i bitno konačnom bitku kako ga misli Heidegger. Ono što on naziva »bitkom « $i$ što od razmjerno ranog naučavanja o »ontologijskoj diferenciji« pa do kasnih razmatranja o »prigodi« nastoji misliti sve dublje i slojevitije po samoj stvari nije daleko od

104

Friedrich Wilhelm Joseph Schelling, »Über die Natur der Philosophie als Wissenschaft $\ll$ (Erlanger Vorträge in den Jahren 1821. 1825. [aus dem handschriftlichen Nachlass]), u: Sämmtliche Werke, Karl Friedrich August Schelling (ur.), sv. IX, J. G. Cotta, Stuttgart, Augsburg 1861., str. 217.

105

Ibid.

106

Ibid., str. 220. Isto to stanje stvari, koje očigledno treba smatrati onim najdubljim i $\mathrm{u}$ najvećoj mjeri središnjim u cjelokupnoj Schellingovoj filozofiji, nalazimo među ostalim i u desetom predavanju kasne filozofije objave (Friedrich Wilhelm Joseph Schelling, Sämmtliche Werke, Karl Friedrich August Schelling (ur.), J. G. Cotta, Stuttgart, Augsburg 1858. sv. XIII, str. 220 i d.), gdje u argumentaciji, koja se očito nastavlja kretati putanjom zacrtanom u najvišoj točki spisa o slobodi, čisto biće, kao »volja koja odlazi od sebe, koja neće samu sebe, volja koja samu sebe ne prihvaća ili koja ne traži ono svoje« biva od onog što može biti, kao onog »koje samo nije htijuće, koje samo može htjeti « i razlikovana i određena kao jedno i isto s njim: »Ono čisto htijuće je kao ništa, upravo zato što sebe ne prihvaća, sebe ne čini vrijediti, ali ono što tek može sama sebe htjeti također je kao ništa, ukoliko sebe neće zbiljski.« Oboje su, takoreći, samo dvije suprotstavljene strane istog bivstva odnosno subjekta, koje ovdje ne biva shvaćeno drukčije nego što je već u spisu o slobodi bio shvaćen »netemelj $\ll$, naime kao »supstancijalna identičnost «: »Ako je dakle ono isto ono što može biti i čisto biće, tad to nije to s uzajamnim isključivanjem, tako da se ovi jedno pod drugim isključuju, nego je to jedno i drugo u supstancijalnoj identičnosti. To je dvojstvo u jedinstvu, to znači to je dvoje, a ipak je supstancijalno samo jedno, $i$ to je jedinstvo $u$ dvojstvu, to znači to je supstancijalno samo jedno, bez da zato manje bude dva.«

107

U tom smjeru upućuje i prosudba Heideggerove kritike Schellinga u Breta H. Davisa, Heidegger and the Will. On the Way to Gelassenheit, Northwestern University Press 2007. Po njegovu mišljenju, Schellingov odnos spram metafizike volje može se označiti »ambivalentnim«. Naime, ostaje nejasno »je li Schelling bio u stanju ontologijsku razinu volje radikalno staviti u pitanje, iako ne samo da smjelo do prikaza dovodi mračne strane volje nego i htijenje kao izvorni bitak svodi na pra-izvornu indiferenciju te kao zadnji cilj volje postulira vječnost čiste, nehtijuće volje« (str. 119 i d.). S obzirom na tu bitnu »ambivalentnost« Heideggerova se kritika Schellingove metafizike volje pokazuje jednostranom i utoliko upitnom: »Pri čitanju između redaka Heideggerove kritike smijemo predmnijevati da su Schellingovi nagovještaji (ma kako zagonetni mogli ostati) o izvornom puštanju da se čini i o slobodi koja 'neće ništa' kao pravoj svrsi sveg htijenja - ili kao odmor od njega - bili među djelotvornim poticajima za Heideggerov vlastiti pokušaj da misli nehtijuću slobodu puštanja biti i opuštenosti.« (Str. 120)

108

Friedrich Wilhelm Joseph Schelling, »Über die Natur der Philosophie als Wissenschaft«, str. 220.

109

To shvaćanje najviše i utoliko istinske slobode provlači se poput crvene niti kroz cjelokupno Schellingovo djelo. Sažeto u gotovo gnomsku formulu, primjerice u Münchenskim predavanjima o razdobljima svijeta iz 1827./28. (Friedrich Wilhelm Joseph Schelling, System der Weltalter. Münchener Vorlesung 1827./28. in einer Nachschrift von Ernst von Lasaulx, Siegbert Peetz (ur.), Vittorio Klostermann, Frankfurt am Main 1990., str. 132) ono glasi: »Ono najviše je: sloboda $z a$ biti $i$ za ne biti.« U kasnoj filozofiji objave, gdje potrebama sustava uvjetovano »apsolutni duh« nastupa kao subjekt odnosno ono noseće apsolutne slobode odnosno indiferencije, isto će se tvrditi o njemu. Usp. Friedrich Wilhelm Joseph Schelling, Urfassung der Philosophie der Offenbarung, sv. 1, Walter E. Ehrhardt (ur.), Felix Meiner, Hamburg 1992., str. 78: »Apsolutni duh nadilazi sve forme. On je duh koji je slobodan od svojega biti duhom - biti duhom njemu je samo jedna forma bitka. Ta sloboda od sama sebe daje mu tek preobilnu slobodu, koja - tako reći - sve posude našeg mišljenja i spoznavanja tako ispunja i proširuje da osjećamo da stojimo na onom najvišem, od čega nema više ničega višeg.« 
Schellingove apsolutne indiferencije. ${ }^{110}$ Naime, bitku mišljenom kao »prigoda « svojstvena je »okretna prekomjernost sama sebe «, uslijed koje on »biva izvorom «. ${ }^{111}$ Moglo bi se ići tako daleko da se u »dvoznačnosti« apsolutne indiferencije, koja, kako smo vidjeli, u Heideggerovoj interpretaciji Schellinga ima tako veliku ulogu, prepozna ista konstelacija koju Heidegger naziva »oklijevanjem« $\mathrm{i} »$ uskraćivanjem«, pod čim se ne smije shvaćati »ni bijeg ni nadolazak (...), ali niti jednako bijeg kao i nadolazak, nego nešto izvornije, punina očuvanja bitka u uskraćivanju «. ${ }^{112}$

Bitak je u Heideggera tako korjenito konačan da se od sama sebe predaje u svaki put drugu ukonačenost, tako da se pruža i tako reći odašilje, otvarajući time svagda drugi povijesni svijet. Kao što ta sebe-odašiljanja bitka nemaju prethodni razlog odnosno temelj, nego se prigađaju bezrazložno i u punoj slobodi, tako se u Schellinga svaka prava odluka zbiva u onom bez-razložnom odnosno bez-temeljnom potpune slobode, možda ne neka od onih što ih čovjek mora često i nevoljko donositi u svojem zbiljskom životu, ali svakako ona kojom u pred-vremenskom i pred-svjesnom inteligibilnom činu biva određen i čvrsto postavljen njegov bitni karakter, a povrh toga i prije svega ona kojom u vječnoj pred-svjetskoj povijesti biva zasnivan svaki od stupnjeva nastajanja samog svijeta.

Iako Heidegger svoju interpretaciju zaključuje naglašenim odbijanjem bezdana i netemelja koji u Schellingovoj filozofiji imaju tako središnje mjesto, na vlastitim putovima mišljenja naoko iznenađujuće i sam dolazi do toga da bitak, dakle ono u njega najviše naprosto, u nekoj vrsti produbljena ponavljanja već spomenute rane misli o slobodi kao »bez-danu tubitka «, ${ }^{113}$ misli kao bezdan. Tako, na primjer, u razmjerno kasnom djelu Stavak razloga kaže:

»Svako obrazlaganje, pa već i svaki privid obrazloživosti morao bi bitak uniziti u neko biće Bitak ostaje kao bitak bez-razložan odnosno bez-temeljan. Temelj, naime kao onaj koji bitak tek utemeljuje, ostaje od bitka daleko i iz njega izostaje. Bitak: bez-temelj.«114

A ako se, možda ponajprije uslijed strasnog misaonog prijepora sa Schellingom, osjetio tako reći slobodom prezasicen, ta je nevoljkost ipak bila kratkotrajna i prolazna. Jer on bez-dan kao izostanak temelja ne misli toliko negativno, dakle naprosto kao povlačenje i odmicanje, koliko kao »iznimnu izvornu vrstu puštanja neispunjenim, praznim; dakle iznimnu vrstu otvaranja ${ }^{115} \mathrm{Bi}$ tak iskušen polazeći od bez-dana odnosno bez-temelja bit će u skladu s tim bitnim stavom dalje mišljen kao »ono otvoreno«, što bi trebalo značiti »ono slobodno raskrčenosti bitka, koji se razlikuje od sveg bića ${ }^{116} \mathrm{Kad} \mathrm{u}$ istom kontekstu ustvrđuje da »još zastrta bit otvorenog kao onog početno sebe-otvarajućeg« nije drugo do upravo »sloboda ${ }^{117}$ ne bi u tomu smjelo biti teško razabrati bitnu blizinu Schellingu.

Heidegger tu bliskost očito nije vidio. On bitak kao bez-dan odnosno bez-temelj određuje kao »ono tla-lišeno«, uz što dodaje objašnjenje: »Tako se zove zato što početno ostaje odriješen od nekog 'tla' i 'temelja' te nešto takvo ni ne treba. ${ }^{118}$ Bitku kao od sveg bića različitom i svem biću uskraćenom, tla lišenom bezdanu - a to znači onom otvorenom kao onom slobodnom raskrčenosti - nema pristupa osim jednog jedinog, koji Heidegger naziva »skokom«:

»Misliti bitak zahtijeva svaki put skok, kojim od naviknutoga tla bića, na kojem je za nas u početku svako biće, odskačemo u ono tla lišeno, kao koje se raskrčuje ono slobodno koje imenujemo kad na biću ne pomišljamo ništa do to da ono 'jest'. ${ }^{119}$

Sloboda, koja se na neko vrijeme činila napuštenom, ovdje je dakle ponovno u igri, i to opet kao nešto sasvim središnje. Skok je »tajnoviti temelj slobo- 
de $\ll,{ }^{120}$ i to tako bitno da se $»$ tek s okružjem skoka otvara bitno područje slobode ${ }^{121}$

Izgleda da ne bi bilo pogrešno u Heideggerovu »skoku« prepoznati stanje stvari u bitnom analogno onomu koje je u Schellinga nazvano »ekstazom«. U našem sklopu dovoljno se ograničiti na iznimno dojmljiv prikaz ekstaze koji Schelling daje u prvom Erlangenškom predavanju. Na Heideggera je on očito učinio snažan dojam; dotična mjesta, premda samo djelomice, on navodi odmah pri početku svojih predavanja iz $1936 .{ }^{122}$ Kako Schelling tamo razlaže, u suočenju s apsolutnom indiferencijom kao istinskim beskonačnim mora

»... sve konačno, sve što je još neko biće, biti napušteno, zadnja privrženost mora iščeznuti; ovdje treba napustiti sve - ne tek, kako se običava govoriti, ženu i dijete, nego sve što samo jest, čak i Boga, jer i Bog je na ovoj točki stajanja samo biće. (...) Tko hoće istinski filozofirati mora se riješiti sve nade, sve težnje, sve čežnje, mora ništa ne htjeti, ništa ne znati, osjećati se posve golim i siromašnim, sve predati, da bi sve stekao. (...) Ali ne samo objekte nego i sama sebe mora napustiti onaj tko se hoće uzdići u onaj slobodni eter.«123

110

Uz to valja općenito napomenuti da se svako istraživanje odnosa Schellinga i Heideggera mora stalno obazirati na upadljivu i dosta zbunjujuću nepodudarnost njihove ontologijske terminologije. Tako na primjer ono što se u Schellinga naziva »bitkom« uopće ne odgovara Heideggerovu »bitku«. Dok ovaj pod tim misli otprilike u sebi ništavno, a to znači bitno prijeporno temeljno zbivanje davanja i pružanja bićevnosti - u kasnijem mišljenju nazivano »prigađanjem« -, koje se kao takvo bitno razlikuje od svakog bića i svega bićevnog, dotle je u Schellinga pod »bitkom« mišljena svakom mišljenju prethodeća, neutemeljiva, tamna i u sebe zatvorena, sve sebi privlačeća i u sebe zatvarajuća - »slijepa«, kako se najčešće određuje - temeljna sila bitka. Hoće li se to uzajamno odstupanje približiti na jednom uvjerljivom primjeru, moglo bi se - kako je u novije vrijeme predloženo (Sebastian Schwenzfeuer, »Natur und Sein - Affinitäten zwischen Schelling und Heidegger«, u: L. Hühn, J. Jantzen (ur.), Heideggers Schelling Seminar (1927./28.), str. 253 i d.) - Schellingov »bitak«, doduše samo uvjetno i otprilike, dovesti u blizinu »Zemlje« iz Heideggerove rasprave o Izvoru umjetničkog djela, a Heideggerov »bitak« s tamo izloženim slobodnim, lakim i rasvjetljujućim »svijetom«. Nešto podrobnije o tom ovdje dotaknutom terminologijskom problemu, koji ipak pri dostatnom obraćanju pozornosti na sve nijanse svakog dotičnog sklopa ne bi morao biti nepopravljivo štetan i činiti nepremostivu prepreku, vidjeti u: Damir Barbarić, »Zeitlichkeit, Sein und Seiendes. Schelling - Heidegger«, u: I. M. Fehér, W. G. Jacobs (ur.), Zeit und Freiheit, str. 215-224, str. 223; također: Pascal David, »Heideggers Deutung von Schellings Freiheitsschrift als Gipfel der Metaphysik des deutschen Idealismus«, u: Harald Seubert (ur.), Heideggers Zwiegespräch mit dem deutschen Idealismus, Böhlau Verlag, Köln Weimar Wien 2003., str. 125-140, str. 138 i d.
111

M. Heidegger, Beiträge zur Philosophie (Vom Ereignis), str. 413

112

Ibid., str. 405.

113

M. Heidegger, »Vom Wesen des Grundes«, str. 174.

114

Martin Heidegger, Der Satz vom Grund, Petra Jaeger (ur.), GA 10, Vittorio Klostermann, Frankfurt am Main 1997., str. 166.

115

M. Heidegger, Beiträge zur Philosophie (Vom Ereignis), str. 379

116

Martin Heidegger, Parmenides, Manfred S. Frings (ur.), GA 54, Vittorio Klostermann, Frankfurt am Main 1982., str. 226.

117

Ibid., str. 213.

118

Ibid., str. 223.

119

Ibid.

120

Martin Heidegger, Einführung in die Metaphysik, Petra Jaeger (ur.), GA 40, Vittorio Klostermann, Frankfurt am Main 1983., str. 15.

121

M. Heidegger, Der Satz vom Grund, str. 139. 122

M., Schellings Abhandlung über das Wesen der menschlichen Freiheit (1809.), str. 7 (= GA 42, str. 10).

123

Friedrich Wilhelm Joseph Schelling, Über die Natur der Philosophie als Wissenschaft, str. $217 \mathrm{i} \mathrm{d}$. 
Ovdje je sve na tomu da se uvidi da to odrješenje od svega što je puko biće, dakle i od Boga i od sama sebe kao bića, nije potpuno gubljenje sebe i iščeznuće u praznom i ništavnom ništa. Naprotiv, time i jedino time nadbićevnoj apsolutnoj slobodi odnosno indiferenciji biva otvoren slobodan prostor, u kojem se ona može pokazati onakvom kakva doista jest. Samoj je stvari primjereno, razlaže Schelling dalje, da se to ukidanje sama sebe nazove »ekstazom « jer u njemu »naše ja [biva] stavljeno izvan sebe, to znači izvan svojega mjesta «. A budući da je mjesto onog ja inače to da bude subjektom, da sve drugo kao objekt odnosno predmet stavlja pred sebe te to tako ima u vlasti kao svoj posjed, ono mora, da bi uopće moglo susresti apsolutni subjekt odnosno vječnu slobodnu indiferenciju, to svoje mjesto napustiti, mora »biti stavljeno izvan sebe, kao neko više uopće ne postojeće «. ${ }^{124}$

Biti subjektom znači prije svega biti onim tko zna i hoće. Zato se čovječje ja u ekstazi kojom on napušta sama sebe kao subjekt mora odreći znanja i htijenja, koji ga inače bitno određuju te ga uvijek i posvuda vode, dakle mora u svojoj najdubljoj srži postati istinski skrušen, da bi tek tako došao u dodir s apsolutnom indiferencijom »kao onim preobilnim«:

»Onaj apsolutni subjekt tu je samo ukoliko ga ne činim predmetom, to znači ukoliko ne znam, ukoliko se ne predajem znanju; ali čim se to neznanje hoće ponovno uspraviti u znanje, on opet iščezava, jer ne može biti objektom. «125

U tako shvaćenoj ekstazi Schelling vidi jedini izlaz iz gotovo dijaboličnog proturječja koje se sastoji u tomu »da čovjek ono što hoće [upravo] svojim htijenjem poništava «. ${ }^{126}$

Ne bi bilo pretjerano ustvrditi da je sve ono što, po Heideggerovu sudu, u Schellinga nije bilo prevladano, već je ostalo i dalje vladajućim i vodećim, Schelling baš tomu nasuprot svojim promišljanjima u nastavku na najvišu točku spisa o slobodi u bitnom ostavio za sobom. Njegova razmatranja o ekstazi Heidegger je doduše poznavao; čak se u svojem prvom suočenju sa Schellingom neko vrijeme s njima misaono hrvao. No, kako svjedoče s tim povezane bilješke, ubrzo je od toga odustao, razočaran, prije svega, time da je taj »ekstatički korak«, protivno Schellingovoj nakani i njegovim uvjeravanjima, tu zapravo »učinjen imanentnim, to znači sadržajem uma «. ${ }^{127}$ Smatrao je da Schelling svojom »ekstazom « nije dospio dalje od savijanja uma unatrag na sebe, dakle još uvijek samo do »refleksije«. Utoliko »stavljanje apsolutne djelatnosti čiste transcendencije izvan sebe vani « ni tu nije izvedeno, tako da ostaje i dalje postojati, i to kao »glavna teškoća (ona idealizma) «. ${ }^{128}$

Ne spominjući, možda se niti ne sjećajući toga da je u istom smjeru i na istom putu već Schelling postigao mnogo toga vrijednog ozbiljne pažnje, Heidegger se u jednom od svojih najodvažnijih i najzahtjevnijih spisa, prema jednom Heraklitovu fragmentu naslovljenim À $\gamma \chi \beta \alpha \sigma i \eta \eta$, upustio u odlučujući pokušaj korjenitog prevladavanja odnosno prebolijevanja svom metafizikom vladajuće volje. Tu nakanu svjesno formulira tako da u njoj sadržana naoko nerazrješiva proturječnost na vidjelo izađe u svoj svojoj nesmiljenoj oštrini: »Ono što (...) zapravo hoću je ne-htijenje.« Daljnji korak sastoji se u potpunom razvijanju aporije koja se krije u toj nakani:

»Ali može li se ne-htijenje htjeti? Pri takvom htijenju htijenje se ipak samo još potencira. Tako htijenje sve odlučnije djeluje upravo protiv onoga što hoće, ne-htijenja. - Protiv volje htijenje se pri htijenju ne-htijenja zapliće u sámo sebe te tako gubi upravo ono što hoće, naime ne-htijenje. $\ll 129$

Međutim, u daljnjem tijeku razgovora postupno se pokazuje da aporija nije tako beznadno nerješiva kako se moglo činiti. Kad bi ljudima jednom uspjelo 
odvratiti se od dosadašnje biti mišljenja - koja se sastoji u tomu da se uvijek unaprijed sebi predočuje i uspostavlja - a time i hoće ${ }^{130}$ - horizont, to znači obzor odnosno vidokrug u kojem nam tek na vidjelo izlaze i pokazuju se izgled i bit predmeta, ${ }^{131}$ moglo bi se nadati da bismo se »barem odvikli od htijenja« te postupno bili pripušteni nečemu takvom kao što je »opuštenost «. ${ }^{132}$

Što se dade razabrati iz ovih čudnovatih nagovještaja, koji zvuče poprilično zanesenjački? Kako i priliči onomu o čemu je tu riječ, Heidegger na to jamačno opravdano pitanje ne daje određeni odgovor, već umjesto toga nudi splet višeznačnih predmnijevanja:

»Možda se u opuštenosti krije aktivnost viša od one u svim činjenjima svijeta i u uradcima čovječanstava. - Samo što ta viša aktivnost ipak nije aktivnost. «133

Ono što ovdje u izgled stavljeni »prijelaz iz htijenja u opuštenost« čini tako krajnje teškim čovjekova je navika - koja mu se svagda pričinja njegovom pravom naravi - da sebe smatra bićem koje hoće, to znači koje predočuje, postavlja i uspostavlja. Upravo to čovjekovo prastaro uvjerenje o njegovoj pravoj naravi, to njegovo uvijek unaprijed pretpostavljeno shvaćanje i određenje sama sebe treba staviti u pitanje i prevladati, da bi se - svakako ne neposredno i odjednom, nego samo na osnovi duge i korak po korak napredujuće pripreme - moglo upustiti u opuštenost, ili točnije biti u nju bilo pripušten:

»Opuštenost je, kao otpuštanje sebe iz transcendentalnog predočavanja, ustvari odvraćanje od htijenja horizonta. To odvraćanje više ni ne dolazi iz htijenja, osim tako da poticaj za upuštanje u pripadnost prigođenu okružju četvorstva treba neki trag htijenja, koji trag međutim u upuštanju iščezava te je naposljetku u pravoj opuštenosti ugašen. ${ }^{134}$

Heidegger u daljnjem razgovoru daje naslutiti, doduše neodređeno i oprezno, da je ta tražena opuštenost nešto poput »suzdržanosti « i da treba počivati na

124

Ibid., str. 229.

125

Ibid.

126

Ibid., str. 235.

127

Martin Heidegger, Seminare Hegel - Schelling, str. 520. Može se usputno napomenuti da se Heidegger pri toj prosudbi u znatnoj mjeri oslonio na ishode utjecajne interpretacije Schellinga koju je na njegov poticaj i pod njegovim očitim utjecajem izradio Walter Schulz.

128

Ibid., str. 521

129

Martin Heidegger, »A $\gamma \chi \curlywedge \beta \alpha \sigma i ́ \eta$. Ein Gespräch selbstdritt auf einem Feldweg zwischen einem Forscher, einem Gelehrten und einem Weisen«, u: Feldweg-Gespräche (1944./45.), Ingrid Schüßler (ur.), GA 77, Vittorio Klostermann, Frankfurt am Main 1995., str. 51. Pri navođenju su izostavljena velika slova koja označavaju sudionike dijaloga. Jedan dio teksta, otprilike zadnju trećinu, Heidegger je pod naslovom $\gg U z$ propitivanje opuštenos- ti - Iz jednog na putu vođenog razgovora o mišljenju « objavio 1959. u knjižici Gelassenheit (str. 29-73). Taj je tekst onda preuzet u svezak 13 Heideggerovih Sabranih djela: Aus der Erfahrung des Denkens, FriedrichWilhelm von Herrmann (ur.), GA 13, Vittorio Klostermann, Frankfurt am Main 1983. str. 37-74.

130

Ibid., str. 91.

131

Ibid., str. 97.

132

Ibid., str. 108.

133

Ibid., str. 108 i d. Usp. Martin Heidegger, »Der Ursprung des Kunstwerkes (1935./36.)«, u: Holzwege, str. 69. Za temu usp. Damir Barbarić, »Sein als Lassen«, u: Zum anderen Anfang, str. 57-69 (hrvatski prijevod: »Bitak kao puštanje«, u: Damir Barbarić, Zrcalna igra četvorstva. Heideggerova kasna misao, Matica hrvatska, Zagreb 2008., str. 37-46).

134

M. Heidegger, »A $\gamma \chi 1 \beta \alpha \sigma i ́ \eta$ «, str. 142 i d. 
»suzdržanu ustrajavanju «, koje bi pak »moglo odgovarati najvišem htijenju, a to ipak ne bi smjelo«. ${ }^{135}$ To suzdržano ustrajavanje ispostavit će se u daljnjem hodu razgovora kao »usrdnost u opuštenosti «i »strpljiva plemenitost «, a ova pak kao »čisto počivanje u sebi one volje koja se, odričući se htijenja, upustila u ono što nije volja ${ }^{136}$

Kako se ova Heideggerova duboka i teško dokučiva razmatranja o opuštenosti odnose spram onih ne manje teških i zagonetnih Schellingovih spekulativnih opisa indiferencije i ekstaze kao jedinog mogućeg puta do nje? Odgovor koji bi bio primjeren samoj stvari morao bi pretpostavljati podrobno i iscrpno interpretativno izlaganje tih dvaju najviših filozofijskih dostignuća, i to kako svakog za sebe tako i obih u njihovu uzajamnom odnosu, što jamačno ne bi bio lagan pothvat. Zadovoljimo se ovdje time da zaključno navedemo Heideggerov stav koji izravno pogađa ishod našeg istraživanja. Prema njemu »najveći mislioci jedan drugog u osnovi nikad ne razumiju, upravo zato što oni, svaki put u obliku njihove jedincate veličine, hoće isto «. ${ }^{137}$

\section{Damir Barbarić}

\section{Indifferenz und Gelassenheit}

\section{Heidegger im Lichte Schellings}

\section{Zusammenfassung}

Der Artikel versucht, die vielfältige und komplexe Beziehung von Heideggers Denken zu Schellings Philosophie zu untersuchen und so genau wie möglich zu bestimmen. Von der anfänglichen Faszination für Schellings zentrale Schrift über die Freiheit, in der er bedeutende Analogien zu seinen eigenen Versuchen findet, die Endlichkeit der Freiheit und damit des Seins selbst nachzuweisen, wird sich Heidegger im weiteren Entwicklung seines Denkens von Schelling immer mehr und immer schärfer distanzieren, indem er ihm vorwirft, die Metaphysik nicht zu überwinden, sondern innerhalb ihres Horizontes zu bleiben, wenn auch auf eine bemerkenswerte und in jeder Hinsicht respektable Weise. Die Angemessenheit dieses Urteils wird im Artikel durch einen kritischen Vergleich und eingehende Begriffsanalyse von Schellings Konzeption von Willen, Liebe, Ekstase und Indifferenz einerseits und Heideggers Auffassung von Bösem, Willen zum Willen, Kehre und Gelassenheit andererseits in Frage gestellt und allseitig überprüft. Als Ergebnis der Untersuchung kommt die sachliche Verwandtschaft dieser zentralen Konzepte der Spätphilosophie des einen und des anderen Denkers ans Licht, die viel größer ist als Heidegger bereit war, es zu sehen, zu akzeptieren und für die letzten Zwecke des eigenen Denkens zu verwenden.

\section{Schlüsselwörter}

Friedrich Wilhelm Joseph Schelling, Martin Heidegger, Freiheit, Wille, Indifferenz, Böse, Gelassenheit das Wesen der menschlichen Freiheit (1809.), str. 15 (= GA 42, str. 21 i d.). 